\title{
Sensing Mechanism of $\mathrm{H}_{2} \mathrm{O}, \mathrm{NH}_{3}$, and $\mathrm{O}_{2}$ on the Stability-Improved $\mathrm{Cs}_{2} \mathrm{~Pb}(\mathrm{SCN})_{2} \mathrm{Br}_{2}$ Surface: A Quantum Dynamics Investigation
}

\author{
Bing Zhang, Xiaogang Wang, Yang Yang, Bin Hu, Lei Tong, Ying Liu, Li Zhao, and Qiang Lu*
}

Cite This: ACS Omega 2021, 6, 24244-24255

Read Online

ABSTRACT: Although the perovskite sensing materials have shown high sensitivity and ideal selectivity toward neutral, oxidative, or reductive gases, their structural instability hampers the practical application. To exploit perovskite-based gas-sensing materials with improved stability and decent sensitivity, three adsorption complexes of $\mathrm{H}_{2} \mathrm{O}, \mathrm{NH}_{3}$, and $\mathrm{O}_{2}$ on the $\mathrm{Cs}_{2} \mathrm{~Pb}$ $(\mathrm{SCN})_{2} \mathrm{Br}_{2}$ surface are built by doping $\mathrm{Br}^{-}$and $\mathrm{Cs}^{+}$in the parent $\left(\mathrm{CH}_{3} \mathrm{NH}_{3}\right)_{2} \mathrm{~Pb}(\mathrm{SCN})_{2} \mathrm{I}_{2}$ structure and submitted to quantum dynamics simulations. Changes in the semiconductor material geometric structures during these dynamic processes are analyzed
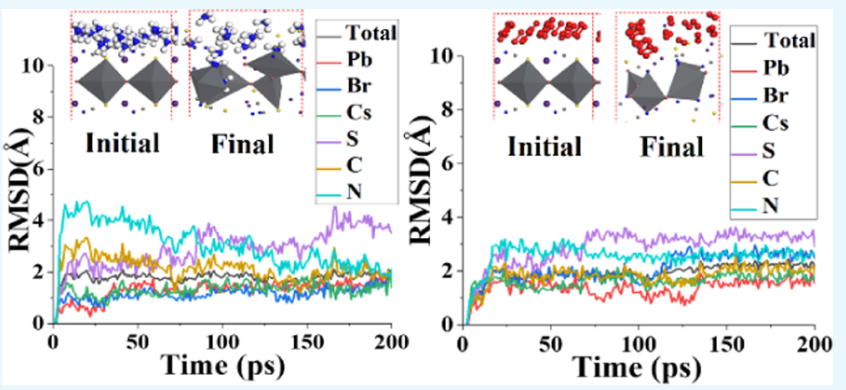
and adsorption ability and charge transfer between $\mathrm{Cs}_{2} \mathrm{~Pb}$ -

$(\mathrm{SCN})_{2} \mathrm{Br}_{2}$ and the gas molecules are explored so as to further establish a correlation between the geometrical structure variations and the charge transfer. By comparing with the previous $\mathrm{CH}_{3} \mathrm{NH}_{3} \mathrm{PbI}_{3}$ and $\left(\mathrm{CH}_{3} \mathrm{NH}_{3}\right)_{2} \mathrm{~Pb}(\mathrm{SCN})_{2} \mathrm{I}_{2}$ adsorption systems, we propose the key factors that enhance the stability of perovskite structures in different atmospheres. The current work is expected to provide clues for developing innovative perovskite sensing materials or for constructing reasonable sensing mechanisms.

\section{INTRODUCTION}

The metal-organic halide perovskite $\mathrm{ABX}_{3}$ has attracted much interest due to its excellent photovoltaic properties. ${ }^{1-5}$ At present, the power conversion efficiency (PCE) of solar cells based on $\mathrm{ABX}_{3}$ structures has exceeded $25.5 \%$; ${ }^{6}$ however, the structural instability of perovskite materials hinders their further development and application in solar cells. ${ }^{7-10}$ Zhao ${ }^{11}$ and $\mathrm{Bao}^{12}$ et al. used $\mathrm{CH}_{3} \mathrm{NH}_{3} \mathrm{PbI}_{3}$ to explore the gas-sensing properties of $\mathrm{NH}_{3}$, which usher in an era of applying perovskite materials in gas sensing. Since then, the detection limit of $\mathrm{O}_{2}$ concentration has been reduced to as low as $70 \mathrm{ppm}$ based on $\mathrm{CH}_{3} \mathrm{NH}_{3} \mathrm{PbI}_{3}$ films, ${ }^{13}$ while $\mathrm{CH}_{3} \mathrm{NH}_{3} \mathrm{PbI}_{3-x} \mathrm{Cl}_{x}$ has been proved to be able to detect an ultralow ozone concentration of few ppb. ${ }^{14}$ These typical experiments have proved the extraordinary sensitivity of the perovskite materials to gases with different reductive or oxidative properties. ${ }^{11-18}$ Differing from the application in solar cells, the range for designing stable perovskite materials for gas sensing can break through the strict limitations on band gaps of photovoltaic materials and hence the interest in the development of such perovskite materials has been triggered.

Despite the extraordinary sensitivity or selectivity of $\mathrm{CH}_{3} \mathrm{NH}_{3} \mathrm{PbI}_{3}$ to gases with various physical or chemical properties, it has been found that the sensing material could be damaged when putting in $\mathrm{NH}_{3}$ (reductive), $\mathrm{H}_{2} \mathrm{O}$ (neutral), and $\mathrm{O}_{2}, \mathrm{NO}_{2}$, or $\mathrm{O}_{3}$ (oxidative) environment. The stability improvement of the gas sensors based on perovskite materials, therefore, remains a major challenge. Our previous quantum dynamics simulations show that $\mathrm{Pb}^{2+}$ with an intermediate valence state exhibits both reduction and oxidation ability, thus it offers active sites that are attacked by both oxidizing and reducing gases, and the weak $\mathrm{Pb}-\mathrm{I}$ framework fails to resist attack by strong oxidative or reductive gases. Further experiments have proved that $\left(\mathrm{CH}_{3} \mathrm{NH}_{3}\right)_{2} \mathrm{~Pb}(\mathrm{SCN})_{2} \mathrm{I}_{2}$, obtained through the partial substitution of the $\mathrm{X}$-site elements in $\mathrm{CH}_{3} \mathrm{NH}_{3} \mathrm{PbI}_{3}$, can improve the perovskite material moisture resistance. ${ }^{19}$ In the simulations of $\left(\mathrm{CH}_{3} \mathrm{NH}_{3}\right)_{2} \mathrm{~Pb}(\mathrm{SCN})_{2} \mathrm{I}_{2}$ adsorbing gases with different properties, i.e., neutral $\mathrm{H}_{2} \mathrm{O}$, reductive $\mathrm{NH}_{3}$, and oxidative $\mathrm{NO}_{2}, \mathrm{O}_{2}$, and $\mathrm{O}_{3}$, it is found what underpins the mechanism of the $\mathrm{SCN}^{-}$groups effectively enhancing the stability of perovskite skeletons is that both the $\mathrm{S}$ atoms and the $\mathrm{CN}$ groups of $\mathrm{SCN}^{-}$can stably bond with $\mathrm{Pb}$. Therefore, the structural stability in the dynamics process is maintained in the form of $\mathrm{Pb}-\mathrm{NCS}$ or $\mathrm{Pb}-\mathrm{SCN}-\mathrm{Pb}$ network structures. However, the weak $\mathrm{Pb}-\mathrm{I}$ bonds in the structure are still the targets of oxidizing or reducing gases. It has been found that both the neutral $\mathrm{H}_{2} \mathrm{O}$ and oxidative gases $\left(\mathrm{NO}_{2}, \mathrm{O}_{2}\right.$, and $\mathrm{O}_{3}$ ) can form a stable $\mathrm{Pb}-\mathrm{O}$ connection by directly attacking the $\mathrm{Pb}-\mathrm{I}$ bonds. ${ }^{20}$ Anyway, in the study of the adsorption of reductive $\mathrm{NH}_{3}$ by $\mathrm{CH}_{3} \mathrm{NH}_{3} \mathrm{PbI}_{3}{ }^{21}$ it is found

Received: August 3, 2021

Accepted: August 24, 2021

Published: September 3, 2021 

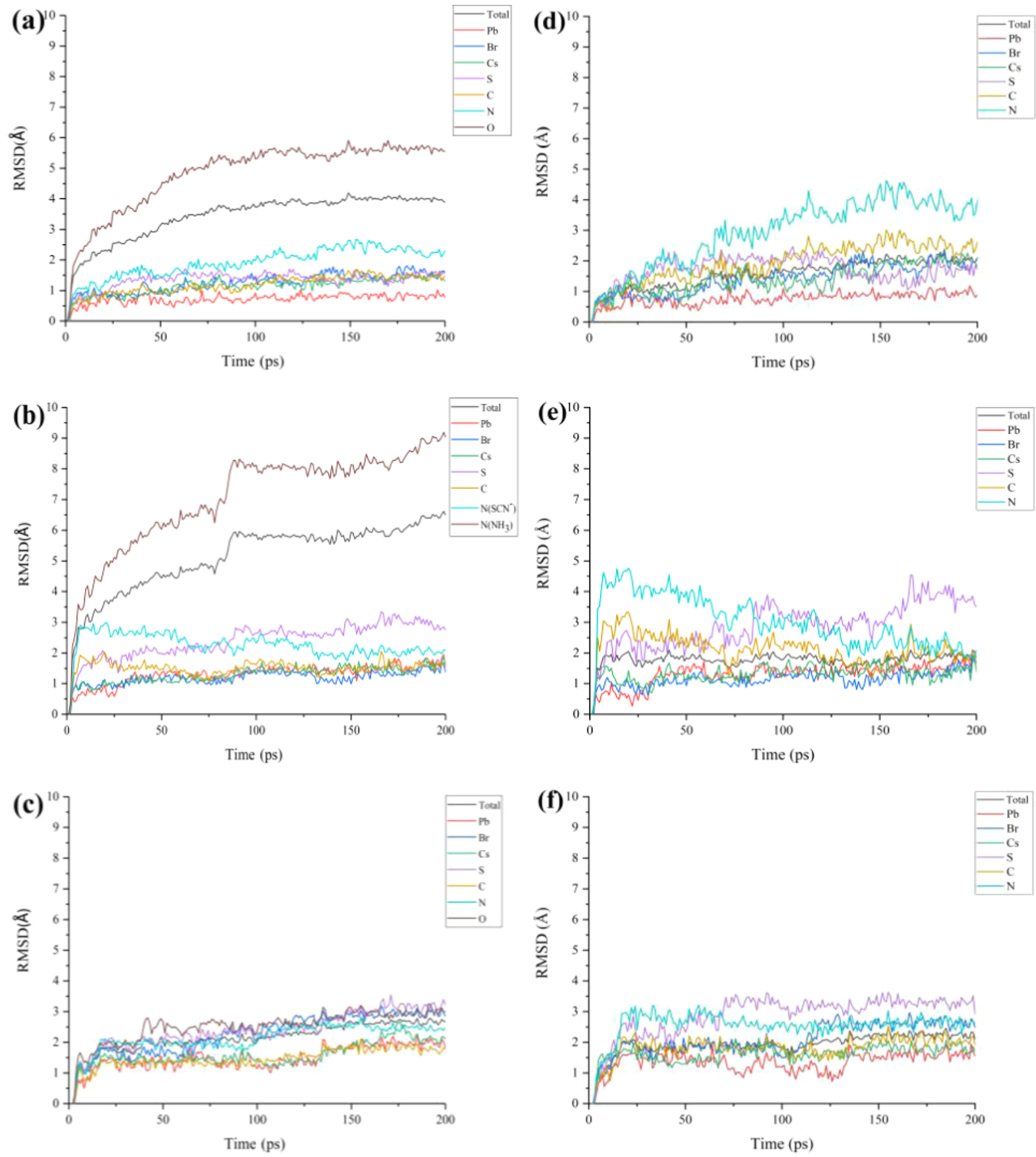

Figure 1. Curves in (a)-(c) are the RMSD of the $\mathrm{Cs} 2 \mathrm{~Pb}(\mathrm{SCN})_{2} \mathrm{Br}_{2}-\mathrm{H}_{2} \mathrm{O}(\mathrm{a}), \mathrm{Cs}_{2} \mathrm{~Pb}(\mathrm{SCN})_{2} \mathrm{Br}_{2}-\mathrm{NH}_{3}(\mathrm{~b})$, and $\mathrm{Cs} \mathrm{Pb}_{2}(\mathrm{SCN})_{2} \mathrm{Br}_{2}-\mathrm{O}_{2}(\mathrm{c})$ complexes, respectively. (d)-(f) Fluctuations of atoms on the $\mathrm{Cs}_{2} \mathrm{~Pb}(\mathrm{SCN})_{2} \mathrm{Br}_{2}$ surface in complexes (a) $-(\mathrm{c})$, respectively.

that the A-site $\mathrm{CH}_{3} \mathrm{NH}_{3}{ }^{+}$groups rapidly adsorb $\mathrm{NH}_{3}$ and undergo $\mathrm{H}$ proton exchanges, thus blocking the interactions between the gas molecules and the skeletons; nevertheless, $\mathrm{NH}_{3}$ can eventually break through the $\mathrm{CH}_{3} \mathrm{NH}_{3}{ }^{+}$barrier and interact with $\mathrm{Pb}$ to achieve stable adsorption and charge exchange. In addition, during the adsorption process, it has been confirmed that the perovskite materials normally receive charges from reductive gases but donate charges to oxidative gases, which is believed to be related to the electron structural changes of the semiconducting materials. ${ }^{21}$

In recent years, the substitution of the original A-site organic groups with inorganic elements or groups to improve the perovskite stability has also been utilized in gas sensing. Experiments have proved that $\mathrm{Cs}_{2} \mathrm{~Pb}(\mathrm{SCN})_{2} \mathrm{I}_{2}$ exhibits enhanced ambient stability compared with $\left(\mathrm{CH}_{3} \mathrm{NH}_{3}\right)_{2} \mathrm{~Pb}$ $(\mathrm{SCN})_{2} \mathrm{I}_{2}{ }^{22}$ In addition, $\mathrm{CsPbBr}_{3}$ has been used to detect 


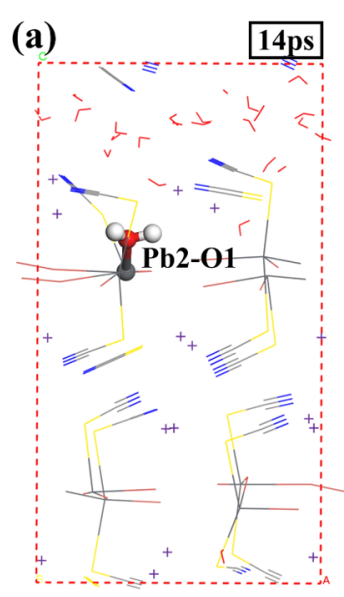

(b)

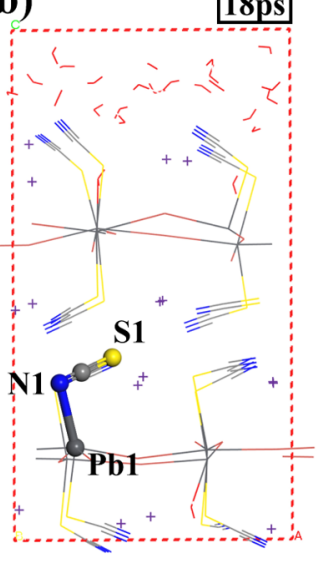

(c)

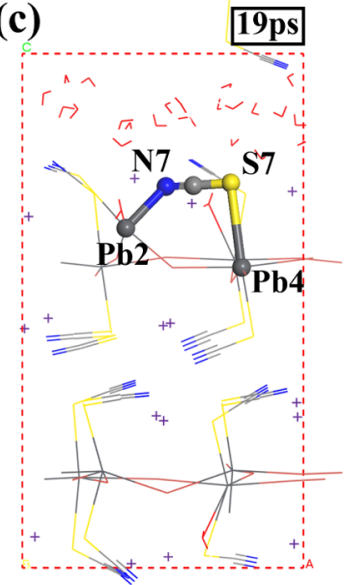

Figure 2. Typical snapshots during the $\mathrm{Cs}_{2} \mathrm{~Pb}(\mathrm{SCN})_{2} \mathrm{Br}_{2}-\mathrm{H}_{2} \mathrm{O}$ simulations: (a) $\mathrm{Pb}$ and $\mathrm{OH}_{2}$ connection, (b) formation of a $\mathrm{Pb}-\mathrm{NCS}$ bond, and (c) formation of a $\mathrm{Pb}-\mathrm{SCN}-\mathrm{Pb}$ network.

volatile organic compounds (acetone and ethanol) with a detection limit as low as $1 \mathrm{ppm}$. In addition, it also provides a fast response and rapid recovery in the detection of $\mathrm{O}_{2} .{ }^{23}$ The excellent stability of $\mathrm{CsPbBr}_{3}$ in air and oxygen has also been verified. $^{24}$

Investigating the gas-sensing mechanisms is the first step leading to the development of ideal sensing materials, while research on adsorption and desorption of gas molecules on the perovskite material surface is the starting point for probing gassensing mechanisms. According to Yamazoe ${ }^{25}$ et al., the initial move in the sensing process of semiconductor-gas molecules is to calibrate gas molecules and their active sites where the gas operates via the electronic changes introduced by gas-solid interactions. Our previous work ${ }^{20,21}$ shows that the structural instability of the perovskite materials causes different dynamic changes around the adsorption sites. Such a property challenges the traditional static first-principles calculations; ${ }^{26-33}$ therefore, the quantum dynamics methodology is employed to deal with such special properties. ${ }^{20,21,34-39}$

In the current work, to improve the structural stability of $\mathrm{CH}_{3} \mathrm{NH}_{3} \mathrm{PbI}_{3}$ and to clarify the sensing mechanism origin of the perovskites toward gases with different oxidationreduction characteristics, the original organic $\mathrm{CH}_{3} \mathrm{NH}_{3}{ }^{+}$groups are replaced by inorganic $\mathrm{Cs}^{+}$and the weak $\mathrm{Pb}-\mathrm{I}$ bonds are substituted by $\mathrm{Pb}-\mathrm{SCN}$ and $\mathrm{Pb}-\mathrm{Br}$. The previously simulated typical neutral $\left(\mathrm{H}_{2} \mathrm{O}\right)$, reductive $\left(\mathrm{NH}_{3}\right)$, and oxidative $\left(\mathrm{O}_{2}\right)$ gases are reselected to form three complexes of $\mathrm{Cs}_{2} \mathrm{~Pb}$ $(\mathrm{SCN})_{2} \mathrm{Br}_{2}-\mathrm{H}_{2} \mathrm{O}, \mathrm{Cs}_{2} \mathrm{~Pb}(\mathrm{SCN})_{2} \mathrm{Br}_{2}-\mathrm{NH}_{3}$, and $\mathrm{Cs}_{2} \mathrm{~Pb}-$ $(\mathrm{SCN})_{2} \mathrm{Br}_{2}-\mathrm{O}_{2}$, respectively. All of the systems are submitted to dynamics simulations. The structural stability of $\mathrm{Cs}_{2} \mathrm{~Pb}$ $(\mathrm{SCN})_{2} \mathrm{Br}_{2}$, under the attack of strong reductive, oxidative, and neutral gas molecules, is described in detail via monitoring the bond breaking and formation during the dynamics processes. The adsorption energy and charge transfer between the perovskite materials and the gases are both quantified. The adsorption details of $\mathrm{H}_{2} \mathrm{O}, \mathrm{NH}_{3}$, and $\mathrm{O}_{2}$ with $\mathrm{CH}_{3} \mathrm{NH}_{3} \mathrm{PbI}_{3}$ and $\left(\mathrm{CH}_{3} \mathrm{NH}_{3}\right)_{2} \mathrm{~Pb}(\mathrm{SCN})_{2} \mathrm{I}_{2}$ are also recalled and compared with systems in the current work. Based on the comparisons, a relationship between the geometrical structure changes of the semiconductor materials and the charge transfer is established. The purpose of this research is to reveal the adsorptiondesorption processes and the stability enhancement mechanisms of $\mathrm{Cs}_{2} \mathrm{~Pb}(\mathrm{SCN})_{2} \mathrm{Br}_{2}$ in an environment containing gases bearing different properties, so as to provide new ideas for developing perovskite sensing materials with improved stability and decent sensitivity.

\section{RESULTS AND DISCUSSION}

The root mean square deviations (RMSDs) of all of the complexes are demonstrated in Figure 1. The RMSD curves of the $\mathrm{Cs}_{2} \mathrm{~Pb}(\mathrm{SCN})_{2} \mathrm{Br}_{2}-\mathrm{H}_{2} \mathrm{O}, \mathrm{Cs}_{2} \mathrm{~Pb}(\mathrm{SCN})_{2} \mathrm{Br}_{2}-\mathrm{NH}_{3}$, and $\mathrm{Cs}_{2} \mathrm{~Pb}(\mathrm{SCN})_{2} \mathrm{Br}_{2}-\mathrm{O}_{2}$ systems tend to be stable at 125,95 , and $145 \mathrm{ps}$, respectively, indicating that the adsorption of the gas molecules on the perovskite skeletons reaches an equilibrium. It takes different time spans for the RMSD curves of the three systems to obtain an equilibrium, and the fluctuations of which are distinct as well, which might suggest that gases with different chemical properties exhibit different adsorption behaviors. The RMSD of the atoms on the perovskite material surface, including $\mathrm{Pb}, \mathrm{Br}, \mathrm{S}, \mathrm{C}$, and $\mathrm{N}$, have also been extracted and described in Figure 1. From the figure, it is clear that the fluctuations of $\mathrm{S}, \mathrm{C}$, and $\mathrm{N}$ on the surface are larger than those of the atoms inside the skeleton. This is in agreement with the structural stability analyses below, where the $-\mathrm{SCN}$ groups on the surface stick out to and are disturbed by the gas molecules to form new $\mathrm{Pb}-\mathrm{SCN}-\mathrm{Pb}$ connections.

2.1. Adsorption Properties of Water Molecules on the $\mathrm{Cs}_{2} \mathrm{~Pb}(\mathrm{SCN})_{2} \mathrm{Br}_{2}$ Surface. The simulations show that, compared with those of the $\mathrm{CH}_{3} \mathrm{NH}_{3} \mathrm{PbI}_{3}$ and $\left(\mathrm{CH}_{3} \mathrm{NH}_{3}\right)_{2} \mathrm{~Pb}$ $(\mathrm{SCN})_{2} \mathrm{I}_{2}$ systems, the stability of $\mathrm{Cs}_{2} \mathrm{~Pb}(\mathrm{SCN})_{2} \mathrm{Br}_{2}$ is further improved in a humid environment. The study of the adsorption of $\mathrm{H}_{2} \mathrm{O}$ on $\mathrm{CH}_{3} \mathrm{NH}_{3} \mathrm{PbI}_{3}$ and $\left(\mathrm{CH}_{3} \mathrm{NH}_{3}\right)_{2} \mathrm{~Pb}$ $(\mathrm{SCN})_{2} \mathrm{I}_{2}$ demonstrates that the breakage of the weak $\mathrm{Pb}-\mathrm{I}$ bonds in the dynamic process is the main reason for the distortion and collapse of the perovskite skeletons under the attack of water molecules. Therefore, in the current work, the changes in the $\mathrm{Pb}-\mathrm{Br}$ bonds in $\mathrm{Cs}_{2} \mathrm{~Pb}(\mathrm{SCN})_{2} \mathrm{Br}_{2}$ are first investigated. In the current dynamics process, a $\mathrm{Pb}-\mathrm{I}$ connection is considered broken when the bond length is stretched longer than $3.4 \AA$ and the threshold is $3.25 \AA$ for a $\mathrm{Pb}-\mathrm{Br}$ connection. ${ }^{40}$ At the end of the simulations, there are 21 intact $\mathrm{Pb}-\mathrm{Br}$ bonds, out of the initial 32 bonds in the system, and the integrity rate is $65.63 \%(21 / 32)$. The integrity rates of $\mathrm{Pb}-\mathrm{I}$ bonds in the $\left(\mathrm{CH}_{3} \mathrm{NH}_{3}\right)_{2} \mathrm{~Pb}(\mathrm{SCN})_{2} \mathrm{I}_{2}$ and $\mathrm{CH}_{3} \mathrm{NH}_{3} \mathrm{PbI}_{3}$ systems are $62.50 \%(20 / 32)$ and $58.33 \%(28 /$ $48)$, respectively. Therefore, the substitution of the original 

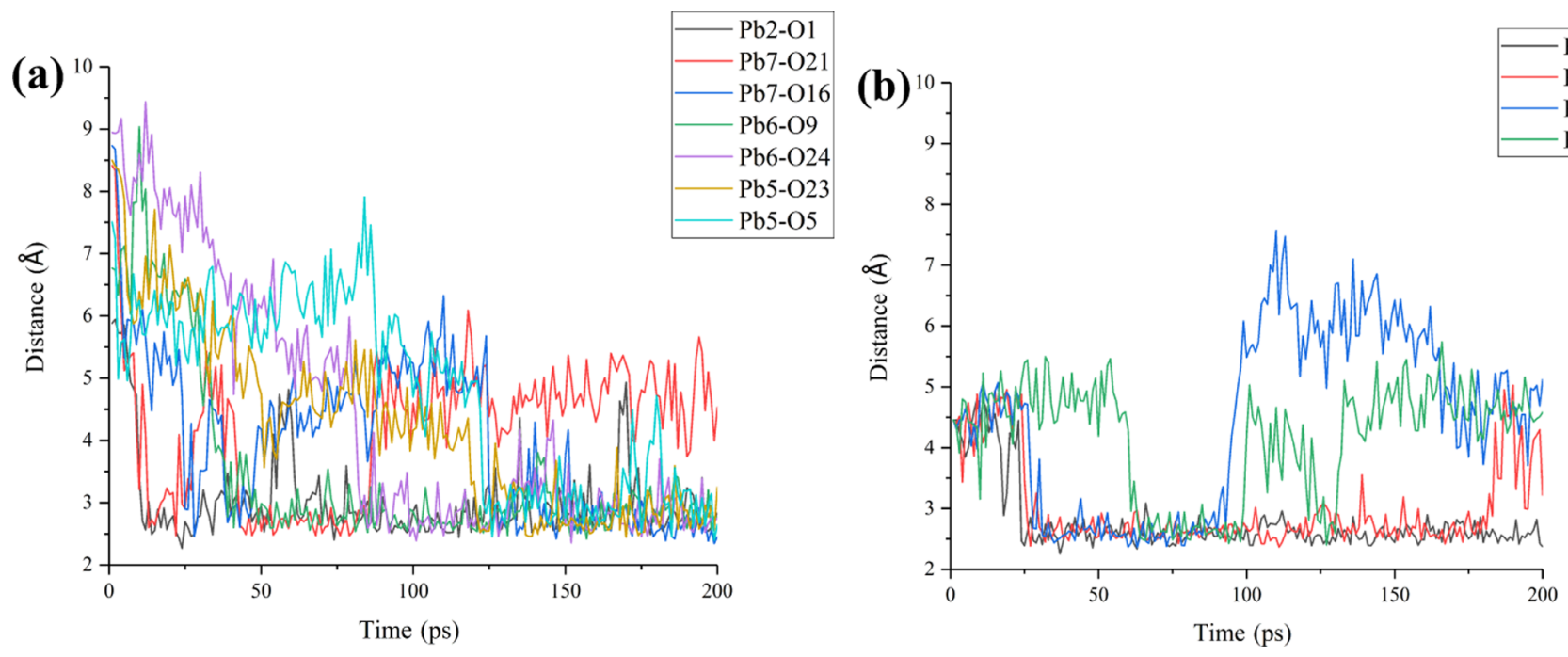

Figure 3. Changes in the new connections in the $\mathrm{Cs}_{2} \mathrm{~Pb}(\mathrm{SCN})_{2} \mathrm{Br}_{2}-\mathrm{H}_{2} \mathrm{O}$ system: (a) $\mathrm{Pb}-\mathrm{O}$ interaction and (b) $\mathrm{Pb}-\mathrm{NCS}$ connection.

$\mathrm{Pb}-\mathrm{I}$ bonds with stronger $\mathrm{Pb}-\mathrm{Br}$ connections can effectively decrease the broken $\mathrm{Pb}-\mathrm{X}$ bond proportion, thus reducing the opportunity for the exposed metal ions to connect with $\mathrm{H}_{2} \mathrm{O}$ molecules. Anyway, a small portion of the $\mathrm{Pb}-\mathrm{Br}$ bonds are still broken under the attack of $\mathrm{H}_{2} \mathrm{O}$ molecules, and $\mathrm{H}_{2} \mathrm{O}$ is found to attack $\mathrm{Pb}$ atoms and form $\mathrm{Pb} 2-\mathrm{O} 1, \mathrm{~Pb} 7-\mathrm{O} 21, \mathrm{~Pb} 7-$ O16, $\mathrm{Pb} 6-\mathrm{O} 9, \mathrm{~Pb} 6-\mathrm{O} 24, \mathrm{~Pb} 5-\mathrm{O} 23$, and $\mathrm{Pb} 5-\mathrm{O} 5$ connections (Figure $2 \mathrm{a}$ ). The distances between these $\mathrm{Pb}$ and $\mathrm{O}$ atoms are mostly slightly longer than the $\mathrm{Pb}-\mathrm{O}$ bond length $(2.49 \AA),{ }^{41}$ indicating that the interactions between $\mathrm{Pb}-\mathrm{OH}_{2}$ are weaker than that of normal $\mathrm{Pb}-\mathrm{O}$ bonds (Figure $3 \mathrm{a}$ ). In the simulations of $\mathrm{CH}_{3} \mathrm{NH}_{3} \mathrm{PbI}_{3}-\mathrm{H}_{2} \mathrm{O}$ and $\left(\mathrm{CH}_{3} \mathrm{NH}_{3}\right)_{2} \mathrm{~Pb}$ $(\mathrm{SCN})_{2} \mathrm{I}_{2}-\mathrm{H}_{2} \mathrm{O}$, the release of reactants $\mathrm{CH}_{3} \mathrm{NH}_{3} \mathrm{I}$ and $\mathrm{CH}_{3} \mathrm{NH}_{3} \mathrm{SCN}$ is observed at 5 and 94 ps (Figure 4),
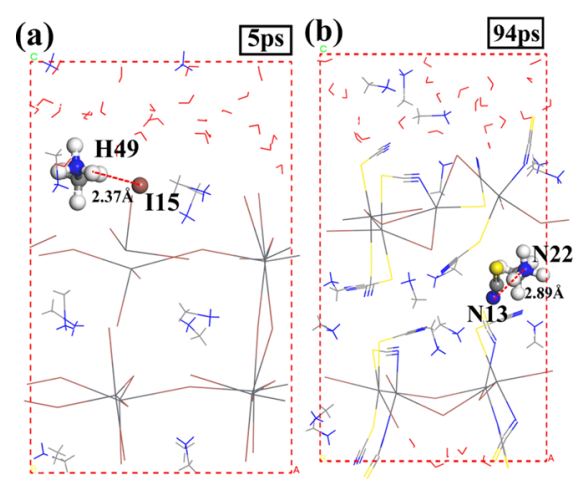

Figure 4. Release of the reactants (a) $\mathrm{CH}_{3} \mathrm{NH}_{3} \mathrm{I}$ and (b) $\mathrm{CH}_{3} \mathrm{NH}_{3} \mathrm{SCN}$.

respectively; no reactant is, however, observed in the $\mathrm{Cs}_{2} \mathrm{~Pb}(\mathrm{SCN})_{2} \mathrm{Br}_{2}-\mathrm{H}_{2} \mathrm{O}$ system. This implies that the doping of $\mathrm{SCN}^{-}$and $\mathrm{Br}^{-}$is conducive to improving the perovskite structural stability.

Furthermore, it has been proved that the formation of stable $\mathrm{Pb}-\mathrm{NCS}$ bonds and $\mathrm{Pb}-\mathrm{SCN}-\mathrm{Pb}$ networks in the $\left(\mathrm{CH}_{3} \mathrm{NH}_{3}\right)_{2} \mathrm{~Pb}(\mathrm{SCN})_{2} \mathrm{I}_{2}$ system is the crucial reason to effectively maintain the stability of perovskite structures. In the $\mathrm{Cs}_{2} \mathrm{~Pb}(\mathrm{SCN})_{2} \mathrm{Br}_{2}-\mathrm{H}_{2} \mathrm{O}$ complex, it is also noticed that $\mathrm{SCN}^{-}$groups rotate in the dynamic process to form $\mathrm{Pb}-\mathrm{NCS}$ bonds (Figure $2 \mathrm{~b}$ ). In view of this phenomenon, the structures of $\mathrm{Cs}_{2} \mathrm{~Pb}(\mathrm{SCN})_{2} \mathrm{Br}_{2}$ and $\mathrm{Cs}_{2} \mathrm{~Pb}(\mathrm{NCS})_{2} \mathrm{Br}_{2}$ are both optimized, and the formation energies are $-124.475 \mathrm{eV}$ and $-124.050 \mathrm{eV}$, respectively (Figure 5). These energies are very similar, (a)

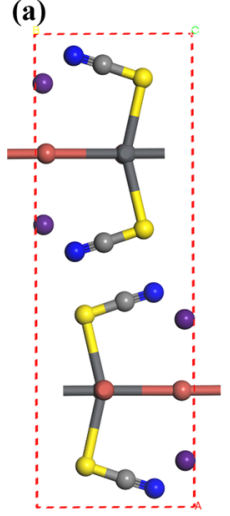

(b)

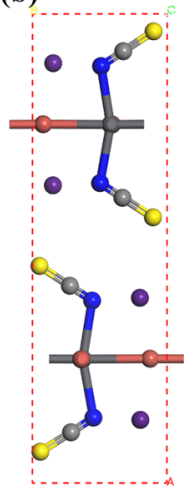

Figure 5. Structural optimization of (a) $\mathrm{Pb}-\mathrm{SCN}$ and (b) $\mathrm{Pb}-\mathrm{NCS}$ connections.

revealing that both connections can exist stably. Furthermore, $\mathrm{Pb} 1-(\mathrm{NCS}) 4, \mathrm{~Pb} 6-(\mathrm{NCS}) 11$, and $\mathrm{Pb} 2-(\mathrm{NCS}) 3$ connections are successively observed (Figure $3 \mathrm{~b}$ ). Moreover, the $\mathrm{Pb} 4-$ (SCN)7-Pb2 network is also detected at 19 ps (Figure 2c).

The stability improvement mechanisms of the perovskite structure by replacing the polar stick-like $\mathrm{CH}_{3} \mathrm{NH}_{3}{ }^{+}$groups with the nonpolar spherical $\mathrm{CS}^{+}$atoms have been proved previously. The rotation of the former is shown to damage the weak $\mathrm{Pb}-\mathrm{I}$ bonds in three-dimensional (3D) skeletons to a certain extent. ${ }^{40} \mathrm{Li}$ et al. ${ }^{22}$ suggested that when $\mathrm{CS}^{+}$is inserted into a two-dimensional (2D) $\left(\mathrm{PbX}_{4}(\mathrm{SCN})_{2}\right)$ framework, smaller $\mathrm{Br}^{-}$that is more strongly bonded with $\mathrm{Pb}^{2+}$ can be used, without serious lattice distortion in air, which is also verified by our simulation results. The comparison of the dynamic fluctuations of the three systems shows that the amplitude of fluctuation of $\mathrm{Cs}^{+}$in the $\mathrm{Cs}_{2} \mathrm{~Pb}(\mathrm{SCN})_{2} \mathrm{Br}_{2}-\mathrm{H}_{2} \mathrm{O}$ system is much smaller than that of $\mathrm{CH}_{3} \mathrm{NH}_{3}{ }^{+}$in the $\mathrm{CH}_{3} \mathrm{NH}_{3} \mathrm{PbI}_{3}-\mathrm{H}_{2} \mathrm{O}$ and $\left(\mathrm{CH}_{3} \mathrm{NH}_{3}\right)_{2} \mathrm{~Pb}(\mathrm{SCN})_{2} \mathrm{I}_{2}-\mathrm{H}_{2} \mathrm{O}$ complexes (Figure $\mathrm{S} 1$ ). In addition, the increased amplitudes of the RMSD curves of $\mathrm{Pb}$ and $\mathrm{Br}$ atoms are smaller than those of $\mathrm{Pb}$ and $\mathrm{I}$ in the $\mathrm{CH}_{3} \mathrm{NH}_{3} \mathrm{PbI}_{3}-\mathrm{H}_{2} \mathrm{O}$ and $\left(\mathrm{CH}_{3} \mathrm{NH}_{3}\right)_{2} \mathrm{~Pb}$ - 
$(\mathrm{SCN})_{2} \mathrm{I}_{2}-\mathrm{H}_{2} \mathrm{O}$ systems, indicating that the substitution of $\mathrm{Cs}^{+}$can stabilize such materials.

2.2. Adsorption Properties of $\mathrm{NH}_{3}$ on the $\mathrm{Cs}_{2} \mathrm{~Pb}$ $(\mathrm{SCN})_{2} \mathrm{Br}_{2}$ Surface. The dynamics results show that without the blockage of $\mathrm{CH}_{3} \mathrm{NH}_{3}{ }^{+}, \mathrm{NH}_{3}$ can rapidly and directly attack $\mathrm{Pb}$ atoms on the $\mathrm{Cs}_{2} \mathrm{~Pb}(\mathrm{SCN})_{2} \mathrm{Br}_{2}$ surface, which is the biggest difference between the $\mathrm{Cs}_{2} \mathrm{~Pb}(\mathrm{SCN})_{2} \mathrm{Br}_{2}-\mathrm{NH}_{3}$ system and the previous $\mathrm{CH}_{3} \mathrm{NH}_{3} \mathrm{PbI}_{3}-\mathrm{NH}_{3}$ system. On the $\mathrm{CH}_{3} \mathrm{NH}_{3} \mathrm{PbI}_{3}$ surface, $\mathrm{NH}_{3}$ molecules do not stably bond with $\mathrm{Pb}$ atoms until 150 ps. $^{21}$ Meanwhile, the $\mathrm{CH}_{3} \mathrm{NH}_{2}$ groups, the products of $\mathrm{CH}_{3} \mathrm{NH}_{3}{ }^{+}-\mathrm{NH}_{3}$ proton exchange, attack $\mathrm{Pb}$ atoms to form a $\mathrm{Pb}-\mathrm{N}$ connection, which survives the rest of the simulations. These $\mathrm{Pb}-\mathrm{NH}_{2} \mathrm{CH}_{3}$ bonds rotate continuously to break the nearby $\mathrm{Pb}-\mathrm{I}$ bonds, which directly leads to the damage of the $\mathrm{Pb}-\mathrm{I}$ skeleton. The reactant $\mathrm{CH}_{3} \mathrm{NH}_{3} \mathrm{I}$ has been observed at 5 ps, as seen in Figure 6 . In the current system, the bond length

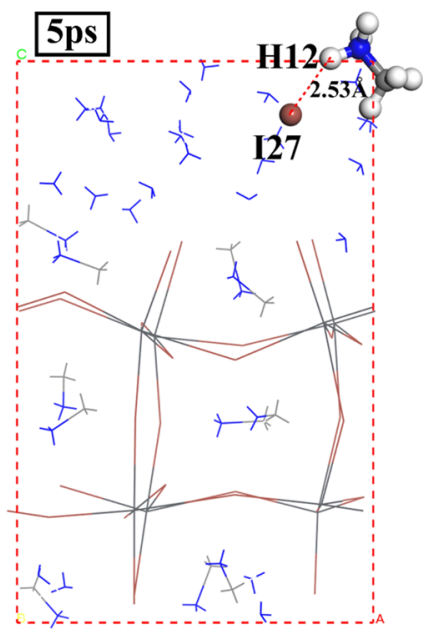

Figure 6. Release of the reactant $\mathrm{CH}_{3} \mathrm{NH}_{3} \mathrm{I}$ in the $\mathrm{CH}_{3} \mathrm{NH}_{3} \mathrm{PbI}_{3}-$ $\mathrm{NH}_{3}$ complex.

of Pb5-N17 reaches $2.41 \AA$ at 20 ps (Figure 7a), which is smaller than the standard $\mathrm{Pb}-\mathrm{N}$ bond length of $2.91 \AA^{42}$ After that, stable connections of $\mathrm{Pb} 3-\mathrm{N} 36, \mathrm{~Pb} 6-\mathrm{N} 23, \mathrm{~Pb} 8-\mathrm{N} 35$, and $\mathrm{Pb} 6-\mathrm{N} 30$ are successively generated at $21,29,51$, and 60 ps, respectively (Figure 8). Pb6-N30 is formed at 60 ps and remains stable until the end of the simulation, and no new $\mathrm{Pb}-$

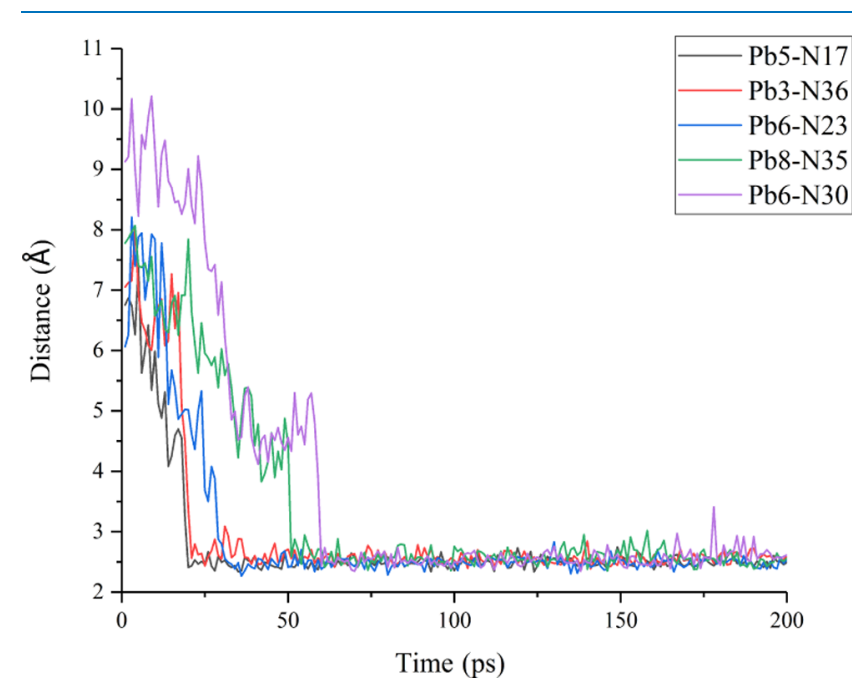

Figure 8. Connection of $\mathrm{Pb}$ and $\mathrm{NH}_{3}$ in the $\mathrm{Cs}_{2} \mathrm{~Pb}(\mathrm{SCN})_{2} \mathrm{Br}_{2}-\mathrm{NH}_{3}$ complex.

$\mathrm{N}$ connections are observed. The $\mathrm{Pb}-\mathrm{NH}_{3}$ bonding does not rotate like $\mathrm{Pb}-\mathrm{NH}_{2} \mathrm{CH}_{3}$ in the $\mathrm{CH}_{3} \mathrm{NH}_{3} \mathrm{PbI}_{3}-\mathrm{NH}_{3}$ complex, while the $\mathrm{Pb}-\mathrm{Br}$ bonds are only partially broken. Therefore, the octahedrons in the perovskite skeletons remain intact without serious distortion or collapse (Figure 9b). At the end of the simulations, the integrity rate of the $\mathrm{Pb}-\mathrm{Br}$ bonds in the $\mathrm{Cs}_{2} \mathrm{~Pb}(\mathrm{SCN})_{2} \mathrm{Br}_{2}-\mathrm{NH}_{3}$ system is $71.88 \%$ (23/32), while that in the $\mathrm{CH}_{3} \mathrm{NH}_{3} \mathrm{PbI}_{3}-\mathrm{NH}_{3}$ complex is $56.25 \%(27 / 48)$.

In addition, both the $\mathrm{Pb}-\mathrm{NCS}$ and $\mathrm{Pb}-\mathrm{SCN}-\mathrm{Pb}$ networks have been observed in the $\mathrm{Cs}_{2} \mathrm{~Pb}(\mathrm{SCN})_{2} \mathrm{Br}_{2}-\mathrm{NH}_{3}$ system (Figure $7 \mathrm{~b}$ ), which also make contributions to improving the stability of the perovskite structures.

2.3. Adsorption Properties of $\mathrm{O}_{2}$ on the $\mathrm{Cs}_{2} \mathrm{~Pb}$ $(\mathrm{SCN})_{2} \mathrm{Br}_{2}$ Surface. In contrast to $\mathrm{H}_{2} \mathrm{O}$ and $\mathrm{NH}_{3}$ that can form stable interactions with exposed lead atoms, the $\mathrm{O}_{2}$ molecules on the perovskite surface are found to be frequently adsorbed and desorbed. As shown in Figure 10a, the distance

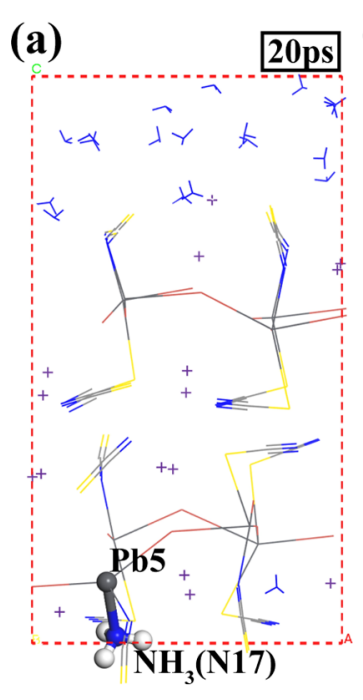

(b)

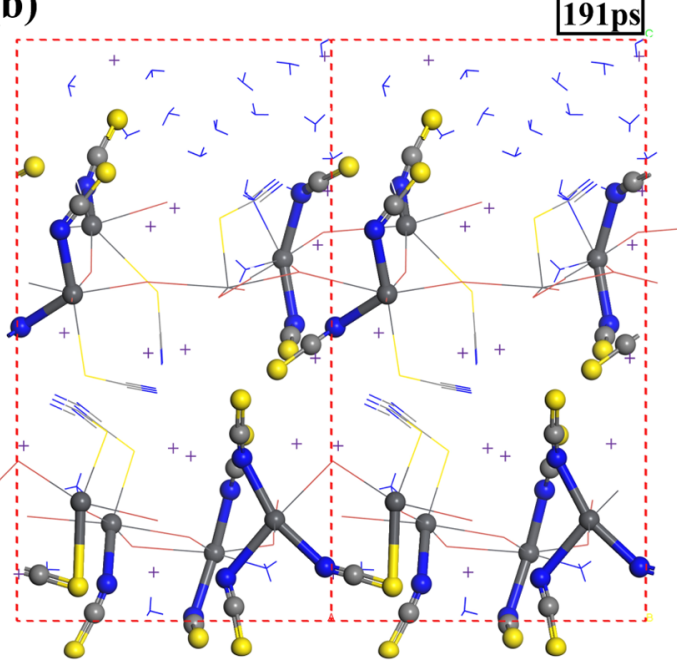

Figure 7. Typical snapshots of the $\mathrm{Cs}_{2} \mathrm{~Pb}(\mathrm{SCN})_{2} \mathrm{Br}_{2}-\mathrm{NH}_{3}$ complex in the current work: (a) $\mathrm{Pb}$ and $\mathrm{NH}_{3}$ connection and (b) formation of $\mathrm{Pb}-$ $\mathrm{NCS}$ and $\mathrm{Pb}-\mathrm{SCN}-\mathrm{Pb}$ networks. 
(a)
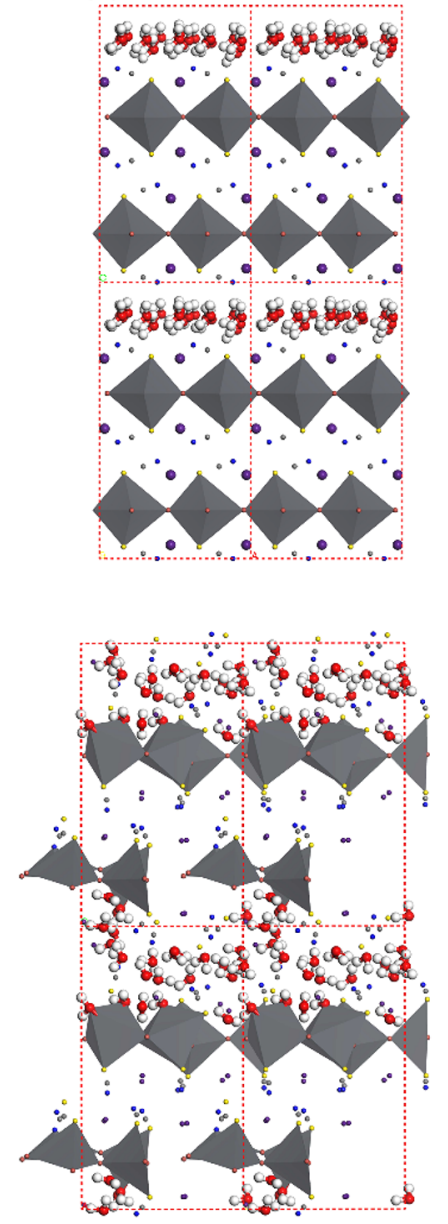

(b)
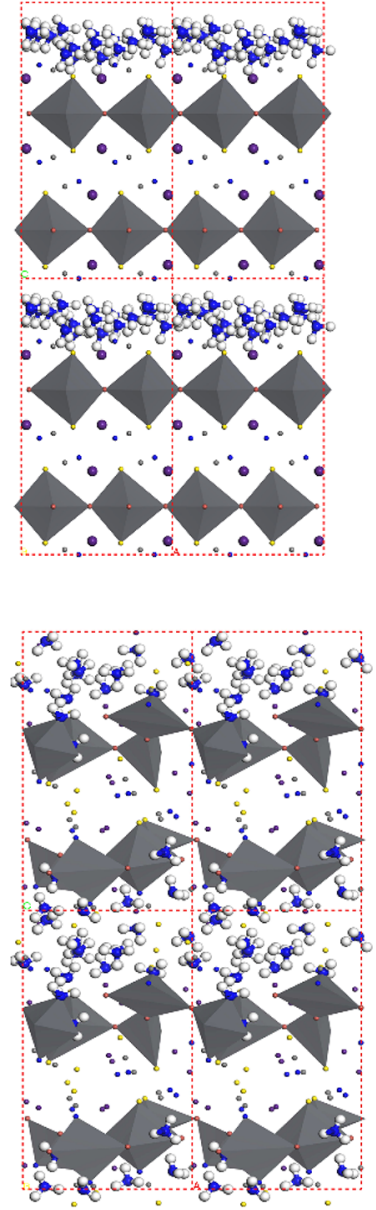

(c)
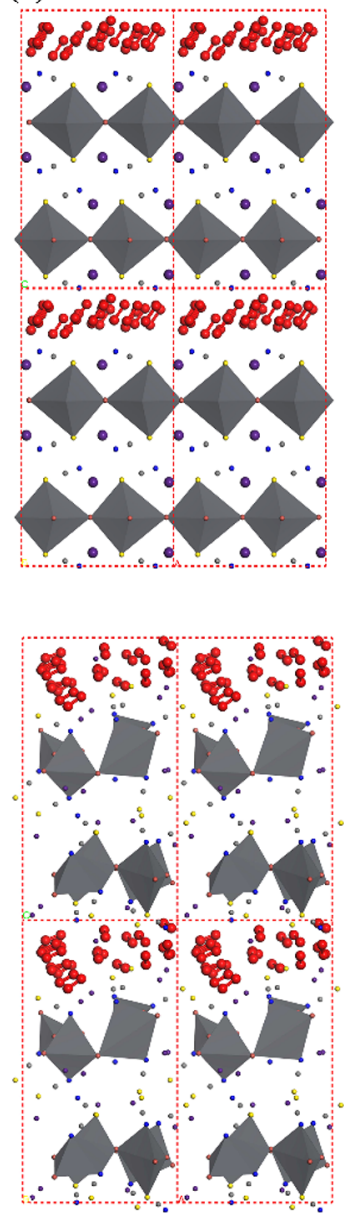

Figure 9. Starting and final structures of the adsorption systems: (a) $\left.\mathrm{Cs}_{2} \mathrm{~Pb}(\mathrm{SCN})_{2} \mathrm{Br}_{2}-\mathrm{H}_{2} \mathrm{O}, \quad(\mathrm{b}) \mathrm{Cs}_{2} \mathrm{~Pb}_{(\mathrm{SCN}}\right)_{2} \mathrm{Br}_{2}-\mathrm{NH} \mathrm{H}_{3}$, and $(\mathrm{c})$ $\mathrm{Cs}_{2} \mathrm{~Pb}(\mathrm{SCN})_{2} \mathrm{Br}_{2}-\mathrm{O}_{2}$.

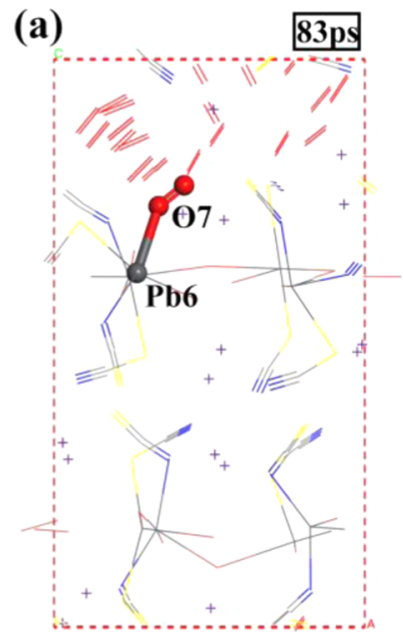

(b)

\section{$200 \mathrm{ps}$}

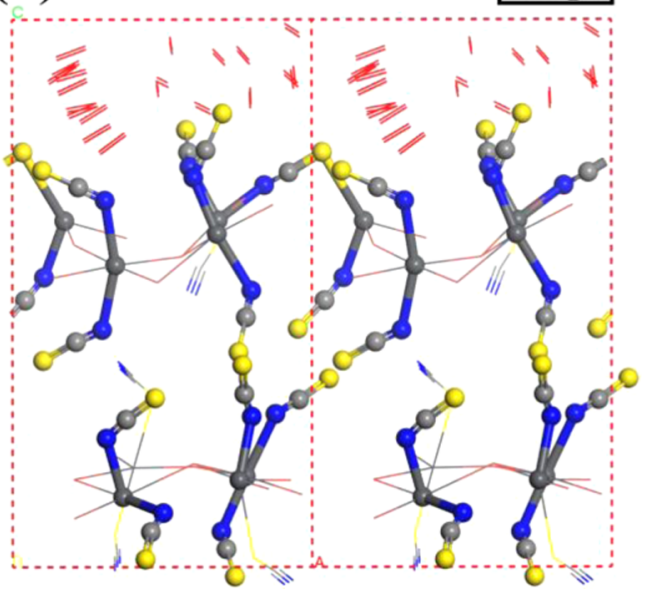

Figure 10. Typical snapshots of the $\mathrm{Cs}_{2} \mathrm{~Pb}(\mathrm{SCN})_{2} \mathrm{Br}_{2}-\mathrm{O}_{2}$ complex: (a) weak $\mathrm{Pb}-\mathrm{O}_{2}$ connection and $(\mathrm{b}) \mathrm{Pb}-\mathrm{NCS}$ and $\mathrm{Pb}-\mathrm{SCN}-\mathrm{Pb}$ networks.

of the Pb6-O7 connection is $2.59 \AA$ at 83 ps, which is longer than the $\mathrm{Pb}-\mathrm{O}$ bond length of $2.49 \AA{ }^{41}$ suggesting a weak interaction between $\mathrm{Pb} 6$ and $\mathrm{O} 7$ (Figure 11a). Such adsorption properties of $\mathrm{O}_{2}$ are also observed on the surfaces of $\mathrm{CH}_{3} \mathrm{NH}_{3} \mathrm{PbI}_{3}$ and $\left(\mathrm{CH}_{3} \mathrm{NH}_{3}\right)_{2} \mathrm{~Pb}(\mathrm{SCN})_{2} \mathrm{I}_{2}$; however, in these two systems, the $\mathrm{O}_{2}$ molecules manage to enter the perovskite lattices by attacking and breaking the $\mathrm{Pb}-\mathrm{I}$ bonds to temporarily bond with $\mathrm{Pb}^{2+}$, which severely damages the material structures (Figure $\mathrm{S} 2$ ). In this study, $\mathrm{O}_{2}$ still cracks the $\mathrm{Pb}-\mathrm{Br}$ bonds. At the end of the simulations, the integrity ratio of $\mathrm{Pb}-\mathrm{Br}$ connections is $62.50 \%(20 / 32)$, which is slightly higher than that of $58.33 \%(28 / 48)$ in the $\mathrm{CH}_{3} \mathrm{NH}_{3} \mathrm{PbI}_{3}-\mathrm{O}_{2}$ system and $43.75 \%(14 / 32)$ in the $\left(\mathrm{CH}_{3} \mathrm{NH}_{3}\right)_{2} \mathrm{~Pb}(\mathrm{SCN})_{2} \mathrm{I}_{2}-$ $\mathrm{O}_{2}$ system. This indicates that the $\mathrm{Pb}-\mathrm{Br}$ bonds are still not 

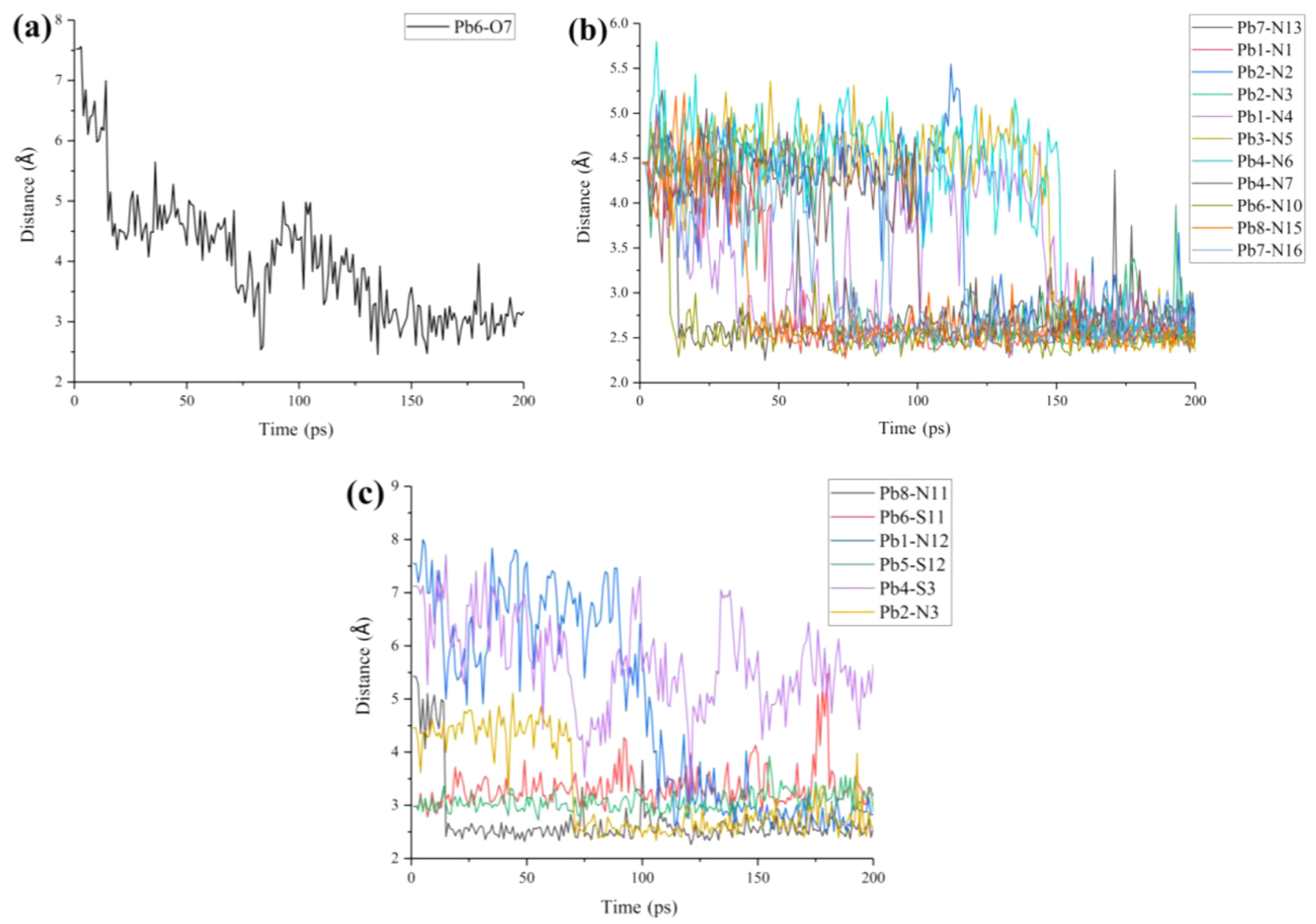

Figure 11. Evolution of the newly formed connections in the $\mathrm{Cs}_{2} \mathrm{~Pb}(\mathrm{SCN})_{2} \mathrm{Br}_{2}-\mathrm{O}_{2}$ complex: (a) interaction of $\mathrm{Pb}-\mathrm{O},(\mathrm{b})$ connection of $\mathrm{Pb}-$ $\mathrm{NCS}$, and (c) formation of $\mathrm{Pb}-\mathrm{SCN}-\mathrm{Pb}$ networks.
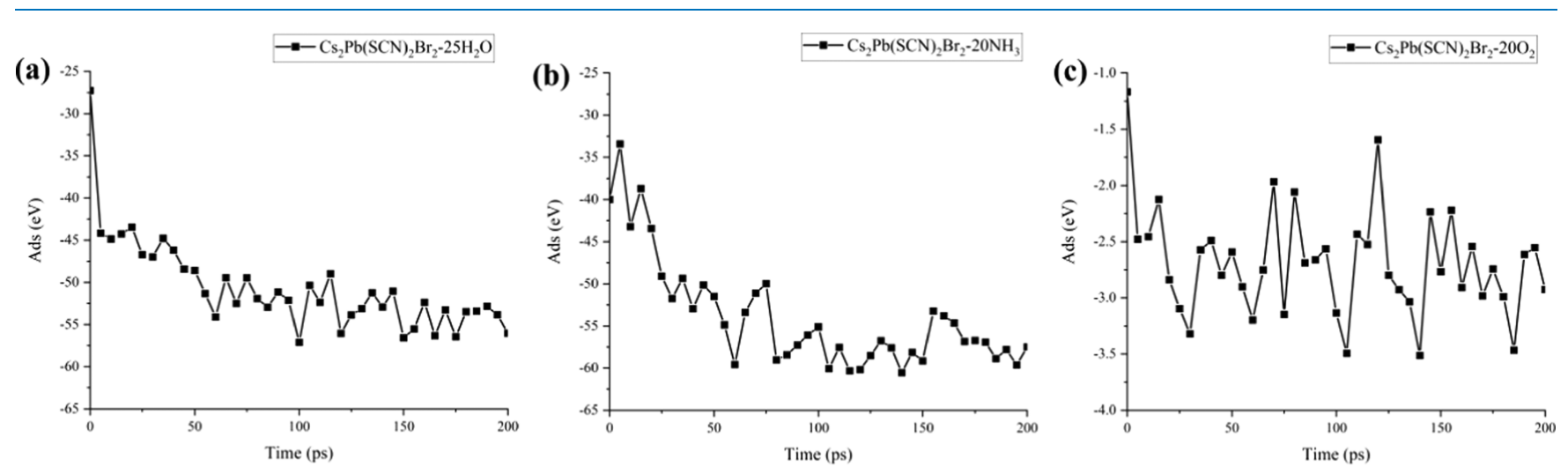

Figure 12. Adsorption energies of (a) $\mathrm{Cs}_{2} \mathrm{~Pb}(\mathrm{SCN})_{2} \mathrm{Br}_{2}-\mathrm{H}_{2} \mathrm{O}$, (b) $\mathrm{Cs}_{2} \mathrm{~Pb}(\mathrm{SCN})_{2} \mathrm{Br}_{2}-\mathrm{NH}_{3}$, and (c) $\left.\mathrm{Cs} \mathrm{sb}_{2} \mathrm{PCN}\right)_{2} \mathrm{Br}_{2}-\mathrm{O}_{2}$ complex.

strong enough under strong oxidizing gas attacks. Despite this, in the $\mathrm{Cs}_{2} \mathrm{~Pb}(\mathrm{SCN})_{2} \mathrm{Br}_{2}-\mathrm{O}_{2}$ system, the $\mathrm{O}_{2}$ molecules are blocked and reside on the surface of perovskite materials and cannot enter the internal of the lattice throughout the simulations (Figure 9c), which is attributed to the contribution of the $\mathrm{Pb}-\mathrm{SCN}$ (Figure 10b).

At the end of the dynamics process of the $\mathrm{Cs}_{2} \mathrm{~Pb}$ $(\mathrm{SCN})_{2} \mathrm{Br}_{2}-\mathrm{O}_{2}$ system, 11 out of $16 \mathrm{~Pb}-\mathrm{SCN}$ transform to $\mathrm{Pb}-\mathrm{NCS}$ connections, that is, $\mathrm{Pb} 1-(\mathrm{NCS}) 1, \mathrm{~Pb} 2-(\mathrm{NCS}) 2$, $\mathrm{Pb} 2-(\mathrm{NCS}) 3, \mathrm{~Pb} 1-(\mathrm{NCS}) 4, \mathrm{~Pb} 3-(\mathrm{NCS}) 5, \mathrm{~Pb} 4-(\mathrm{NCS}) 6$, $\mathrm{Pb} 4-(\mathrm{NCS}) 7, \mathrm{~Pb} 6-(\mathrm{NCS}) 10, \mathrm{~Pb} 8-(\mathrm{NCS}) 15, \mathrm{~Pb} 7-(\mathrm{NCS})-$
16 , and $\mathrm{Pb} 7-(\mathrm{NCS}) 13$ (Figure $11 \mathrm{~b}$ ). In the $\mathrm{Cs}_{2} \mathrm{~Pb}$ $(\mathrm{SCN})_{2} \mathrm{Br}_{2}-\mathrm{H}_{2} \mathrm{O}$ and $\mathrm{Cs}_{2} \mathrm{~Pb}(\mathrm{SCN})_{2} \mathrm{Br}_{2}-\mathrm{NH}_{3}$ complexes, the number of $\mathrm{Pb}-\mathrm{NCS}$ is 1 and 8 , respectively. The reason of which is further analyzed in the following charge transfer section. In addition, the Pb6-(SCN)11-Pb8, Pb5-(SCN)$12-\mathrm{Pb} 1$, and $\mathrm{Pb} 4-(\mathrm{SCN}) 3-\mathrm{Pb} 2$ networks are observed (Figure $11 \mathrm{c}$, the normal bond length of $\mathrm{Pb}-\mathrm{S}$ is $3.70 \AA^{43}$ ). It is these special forms that are deemed to prevent $\mathrm{O}_{2}$ molecules from entering the perovskite lattice, thus ensuring the structural integrity of the semiconductor materials. 

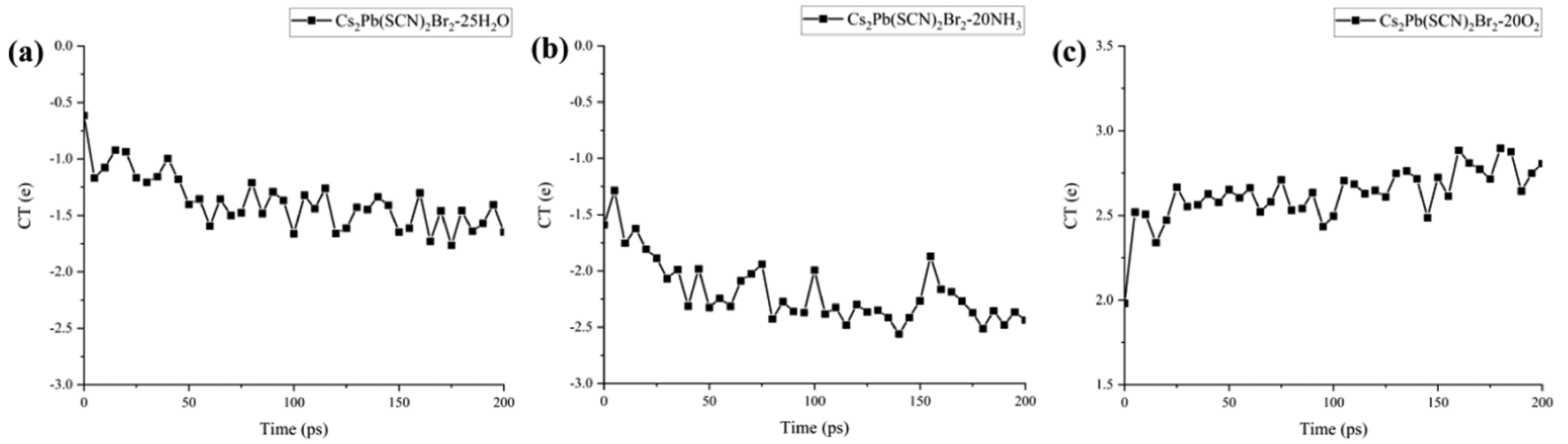

Figure 13. Charge transfer of (a) $\mathrm{Cs}_{2} \mathrm{~Pb}(\mathrm{SCN})_{2} \mathrm{Br}_{2}-\mathrm{H}_{2} \mathrm{O}$, (b) $\mathrm{Cs}_{2} \mathrm{~Pb}(\mathrm{SCN})_{2} \mathrm{Br}_{2}-\mathrm{NH}_{3}$, and (c) $\mathrm{Cs}_{2} \mathrm{~Pb}(\mathrm{SCN})_{2} \mathrm{Br}_{2}-\mathrm{O}_{2}$ complex.

From the above analyses, it can be seen that, during the adsorption processes, the $-\mathrm{SCN}$ groups on the $\mathrm{Cs}_{2} \mathrm{~Pb}$ $(\mathrm{SCN})_{2} \mathrm{Br}_{2}$ surface are first affected by the gas molecules and different connections are detected, which is consistent with the RMSD curve fluctuations of the surface $\mathrm{S}, \mathrm{C}$, and $\mathrm{N}$ atoms.

The following quantitative data of the adsorption energy and charge transfer are used to depict the adsorption properties of the three systems.

2.4. Adsorption Ability of $\mathrm{H}_{2} \mathrm{O}, \mathrm{NH}_{3}$, and $\mathrm{O}_{2}$ on the $\mathrm{Cs}_{2} \mathrm{~Pb}(\mathrm{SCN})_{2} \mathrm{Br}_{2}$ Surface. Figure 12 and Table S1 demonstrate the data of the adsorption energies of the $\mathrm{Cs}_{2} \mathrm{~Pb}$ $(\mathrm{SCN})_{2} \mathrm{Br}_{2}-\mathrm{H}_{2} \mathrm{O}, \mathrm{Cs}_{2} \mathrm{~Pb}(\mathrm{SCN})_{2} \mathrm{Br}_{2}-\mathrm{NH}_{3}$, and $\mathrm{Cs}_{2} \mathrm{~Pb}-$ $(\mathrm{SCN})_{2} \mathrm{Br}_{2}-\mathrm{O}_{2}$ complexes. The negative adsorption energy $\left(E_{\text {ad }}\right)$ implies the reactions are exothermic and spontaneous. This indicates that the gas molecules are adsorbed on the $\mathrm{Cs}_{2} \mathrm{~Pb}(\mathrm{SCN})_{2} \mathrm{Br}_{2}$ surface; the larger adsorption energy suggests that more energy is released during the reaction and more stable connections are established. For the $\mathrm{Cs}_{2} \mathrm{~Pb}(\mathrm{SCN})_{2} \mathrm{Br}_{2}-$ $\mathrm{NH}_{3}$ system, in the initial phase of the dynamics process, the $\mathrm{NH}_{3}$ molecules attack $\mathrm{Pb}$ atoms to form a stable $\mathrm{Pb}-\mathrm{N}$ connection; however, the presence of $\mathrm{Pb}-\mathrm{SCN}$ and $\mathrm{Pb}-\mathrm{NCS}$ connections on the surface prevents more $\mathrm{NH}_{3}$ molecules from attacking $\mathrm{Pb}$ atoms and the average adsorption energy of the system in the equilibrium stage is $-57.611 \mathrm{eV}$. For the $\mathrm{Cs}_{2} \mathrm{~Pb}(\mathrm{SCN})_{2} \mathrm{Br}_{2}-\mathrm{H}_{2} \mathrm{O}$ system, $\mathrm{Pb}$ atoms are still active sites that are first attacked by the $\mathrm{H}_{2} \mathrm{O}$ molecules. Although the number of the newly formed $\mathrm{Pb}-\mathrm{OH}_{2}$ connections is larger than that of the $\mathrm{Pb}-\mathrm{N}$ bonds mentioned above, the average adsorption energy of the system in the equilibrium stage is slightly lower, $-53.678 \mathrm{eV}$. This is mainly due to the relatively weak $\mathrm{Pb}-\mathrm{OH}_{2}$ connections as discussed in Section 2.1. Furthermore, considering that the total number of $\mathrm{H}_{2} \mathrm{O}$ molecules is 25 and that of $\mathrm{NH}_{3}$ is 20 , the adsorption ability of a single $\mathrm{NH}_{3}$ is stronger than that of a single $\mathrm{H}_{2} \mathrm{O}$ molecule. In contrast, the $\mathrm{Cs}_{2} \mathrm{~Pb}(\mathrm{SCN})_{2} \mathrm{Br}_{2}-\mathrm{O}_{2}$ system is more special. Due to the frequent adsorption-desorption behaviors of $\mathrm{O}_{2}$ in the dynamic process, the adsorption energy of the system is relatively lower than the above discussed two complexes, which is $-2.781 \mathrm{eV}$. This phenomenon seems to fulfill the requirements of an ideal gas-sensing system, where the gas molecule under detection is not only easily adsorbed but also easily released from the sensing material surface.

2.5. Charge Transfer between $\mathrm{Cs}_{2} \mathrm{~Pb}(\mathrm{SCN})_{2} \mathrm{Br}_{2}$ and $\mathrm{H}_{2} \mathrm{O}, \mathrm{NH}_{3}$, and $\mathrm{O}_{2}$. Charge transfer is one of the most crucial factors influencing the resistivity of sensing materials. The calculated Bader charges are shown in Figure 13 and Table S2. In the initial stage, the quantity of the charge transfers from
$\mathrm{H}_{2} \mathrm{O}$ to $\mathrm{Cs}_{2} \mathrm{~Pb}(\mathrm{SCN})_{2} \mathrm{Br}_{2}$ is 0.616 e. In this case, both $\mathrm{Pb}^{2+}$ $(-4.869 \mathrm{e})$ and $\mathrm{Cs}^{+}(-9.870 \mathrm{e})$ in the $\mathrm{Cs}_{2} \mathrm{~Pb}(\mathrm{SCN})_{2} \mathrm{Br}_{2}-\mathrm{H}_{2} \mathrm{O}$ system lose charges. The charges gained by $\mathrm{SCN}^{-}$and $\mathrm{Br}^{-}$are $7.967 \mathrm{e}$ and $7.352 \mathrm{e}$, respectively. At the end of the dynamics process, the charge transferred from $\mathrm{H}_{2} \mathrm{O}$ to $\mathrm{Cs}_{2} \mathrm{~Pb}(\mathrm{SCN})_{2} \mathrm{Br}_{2}$ is $1.647 \mathrm{e}$, and those of $\mathrm{Pb}^{2+}, \mathrm{Cs}^{+}, \mathrm{SCN}^{-}$, and $\mathrm{Br}^{-}$are $-4.954 \mathrm{e}$, -9.913 e, 9.253 e, and 7.261 e, respectively. Therefore, during the dynamics processes, the donors in the $\mathrm{Cs}_{2} \mathrm{~Pb}(\mathrm{SCN})_{2} \mathrm{Br}_{2}-$ $\mathrm{H}_{2} \mathrm{O}$ system are $\mathrm{H}_{2} \mathrm{O}(-1.031 \mathrm{e}), \mathrm{Pb}^{2+}(-0.085 \mathrm{e}), \mathrm{Cs}^{+}(-0.043$ $\mathrm{e})$, and $\mathrm{Br}^{-}(-0.091 \mathrm{e})$, respectively, while the acceptor is $\mathrm{SCN}^{-}(1.286 \mathrm{e})$. Similarly, for the $\mathrm{Cs}_{2} \mathrm{~Pb}(\mathrm{SCN})_{2} \mathrm{Br}_{2}-\mathrm{NH}_{3}$ system, the donors are $\mathrm{NH}_{3}, \mathrm{~Pb}^{2+}$, and $\mathrm{Cs}^{+}$, donating -0.848 e, $-0.141 \mathrm{e}$, and $-0.088 \mathrm{e}$, respectively. The acceptors are $\mathrm{SCN}^{-}$and $\mathrm{Br}^{-}$, respectively, accepting 0.370 e and 0.714 e. In the $\mathrm{Cs}_{2} \mathrm{~Pb}(\mathrm{SCN})_{2} \mathrm{Br}_{2}-\mathrm{O}_{2}$ complex, the donors are $\mathrm{Pb}^{2+}$ and $\mathrm{Br}^{-}$, which separately provide $-0.209 \mathrm{e}$ and $-0.708 \mathrm{e}$, respectively. The acceptors are $\mathrm{O}_{2}, \mathrm{Cs}^{-}$, and $\mathrm{SCN}^{-}$, accepting $0.824 \mathrm{e},-0.150 \mathrm{e}$, and $0.244 \mathrm{e}$, respectively.

$\mathrm{Pb}^{2+}$ has both oxidizing and reducing properties. In the current work, $\mathrm{Pb}^{2+}$ loses charge, showing different degrees of reducibility, which may be related to the strong electronwithdrawing halogen or the pseudo-halogen groups connected with $\mathrm{Pb}^{2+}$. In view of the formation of the multiple $\mathrm{Pb}-\mathrm{NCS}$ connections and the strong electron-withdrawing capacity of the $-\mathrm{CN}$ groups, the relationship between the charge loss of $\mathrm{Pb}$ atoms and the number of $\mathrm{Pb}-\mathrm{NCS}$ connections is proved, as shown in Table 1 and Figure 14. The data show that there is

Table 1. Relationship between the Loss of Charges of $\mathrm{Pb}$ Atoms and the Number of $\mathbf{P b}-\mathrm{NCS}$ Connections

\begin{tabular}{|c|c|c|c|c|c|}
\hline \multicolumn{2}{|c|}{$\mathrm{Cs}_{2} \mathrm{~Pb}(\mathrm{SCN}){ }_{2} \mathrm{Br}_{2}-\mathrm{H}_{2} \mathrm{O}$} & \multicolumn{2}{|c|}{$\mathrm{Cs}_{2} \mathrm{~Pb}(\mathrm{SCN})_{2} \mathrm{Br}_{2}-\mathrm{NH}_{3}$} & \multicolumn{2}{|c|}{$\mathrm{Cs}_{2} \mathrm{~Pb}(\mathrm{SCN})_{2} \mathrm{Br}_{2}-\mathrm{O}_{2}$} \\
\hline $\begin{array}{l}\text { number of } \\
\mathrm{Pb}-\mathrm{NCS} \\
\text { connections }\end{array}$ & $\begin{array}{l}\text { charge } \\
\text { donated } \\
\text { by } \mathrm{Pb}^{2+} \\
\text { (e) }\end{array}$ & $\begin{array}{l}\text { number of } \\
\mathrm{Pb}-\mathrm{NCS} \\
\text { connections }\end{array}$ & $\begin{array}{l}\text { charge } \\
\text { donated } \\
\text { by } \mathrm{Pb}^{2+} \\
\text { (e) }\end{array}$ & $\begin{array}{l}\text { number of } \\
\mathrm{Pb}-\mathrm{NCS} \\
\text { connections }\end{array}$ & $\begin{array}{c}\text { charge } \\
\text { donated } \\
\text { by } \mathrm{Pb}^{2+} \\
\text { (e) }\end{array}$ \\
\hline 4 & -0.111 & 4 & -0.060 & 4 & 0.011 \\
\hline 3 & -0.091 & 6 & -0.071 & 7 & -0.035 \\
\hline 1 & -0.085 & 8 & -0.140 & 11 & -0.227 \\
\hline
\end{tabular}

an obvious linear correlation between them in all three systems. Based on the above analysis, $\mathrm{Pb}^{2+}$ is a crucial active site and the gas molecules $-\mathrm{Pb}^{2+}-\mathrm{SCN}^{-}$connections are the main charge-transfer channels. Combined with the above structural stability analysis, although the stability of $\mathrm{Pb}-\mathrm{SCN}$ and $\mathrm{Pb}-\mathrm{NCS}$ is similar, considering the stronger electronwithdrawing properties of the $-\mathrm{CN}$ groups, more $\mathrm{Pb}-\mathrm{NCS}$ connections indicate stronger electron-accepting ability during 


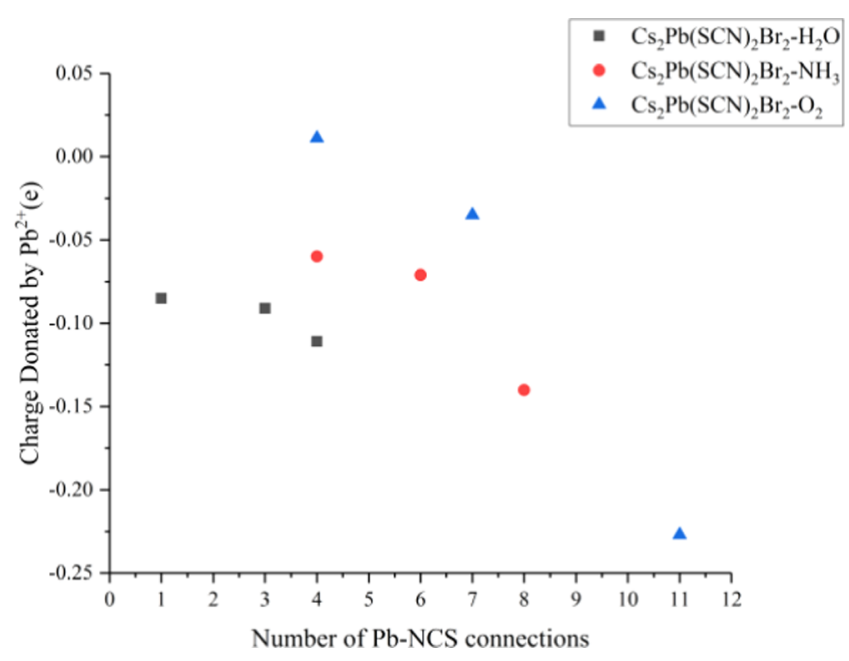

Figure 14. Relationship between the loss of charges of $\mathrm{Pb}$ atoms and the number of $\mathrm{Pb}-\mathrm{NCS}$ connections.

the adsorption of various gas molecules. In the three systems, with the increase in the number of $\mathrm{Pb}-\mathrm{NCS}$ bonds, $\mathrm{Pb}^{2+}$ loses more charge, showing stronger oxidizability. For the neutral $\mathrm{H}_{2} \mathrm{O}$ and reductive $\mathrm{NH}_{3}$, the systems receive charges. In terms of the strong oxidizing $\mathrm{O}_{2}$, these systems still lose charges.

2.6. Influences on the Band Gap of $\mathrm{Cs}_{2} \mathrm{~Pb}(\mathrm{SCN})_{2} \mathrm{Br}_{2}$ from the Adsorption of $\mathrm{H}_{2} \mathrm{O}, \mathrm{NH}_{3}$, and $\mathrm{O}_{2}$. The band gap values of $\mathrm{Cs}_{2} \mathrm{~Pb}(\mathrm{SCN})_{2} \mathrm{Br}_{2}$ before and after the adsorption of the gas molecules were calculated and are listed in Table 2. To

Table 2. Band Gap Variations due to the Different ChargeTransfer Processes

\begin{tabular}{|c|c|c|c|c|c|}
\hline \multicolumn{2}{|c|}{$\mathrm{Cs}_{2} \mathrm{~Pb}(\mathrm{SCN})_{2} \mathrm{Br}_{2}-\mathrm{H}_{2} \mathrm{O}$} & \multicolumn{2}{|c|}{$\mathrm{Cs}_{2} \mathrm{~Pb}(\mathrm{SCN})_{2} \mathrm{Br}_{2}-\mathrm{NH}_{3}$} & \multicolumn{2}{|c|}{$\mathrm{Cs}_{2} \mathrm{~Pb}(\mathrm{SCN})_{2} \mathrm{Br}_{2}-\mathrm{O}_{2}$} \\
\hline $\begin{array}{l}\text { time } \\
\text { (ps) }\end{array}$ & $\begin{array}{c}\text { band gap } \\
(\mathrm{eV})\end{array}$ & $\begin{array}{l}\text { time } \\
\text { (ps) }\end{array}$ & $\begin{array}{c}\text { band gap } \\
(\mathrm{eV})\end{array}$ & $\begin{array}{l}\text { time } \\
\text { (ps) }\end{array}$ & $\begin{array}{c}\text { band gap } \\
(\mathrm{eV})\end{array}$ \\
\hline 80 & 1.024 & 105 & 1.076 & 83 & 0.443 \\
\hline 140 & 1.006 & 140 & 1.182 & 145 & 0.542 \\
\hline 175 & 1.190 & 185 & 1.132 & 184 & 0.767 \\
\hline
\end{tabular}

clearly show the band gap tuning of the semiconductor materials from gas sensing, the structures, in which the stable connections between the gas molecules and the surface of $\mathrm{Cs}_{2} \mathrm{~Pb}(\mathrm{SCN})_{2} \mathrm{Br}_{2}$ were formed (Figure $\mathrm{S} 3$ ), were selected and calculated. The band gap value of $0.794 \mathrm{eV}$ refers to the pure perovskite material. After adsorption, as seen in Figure 13 and Table 2, when reductive $\mathrm{NH}_{3}$ or neutral $\mathrm{H}_{2} \mathrm{O}$ molecules were involved, $\mathrm{Cs}_{2} \mathrm{~Pb}(\mathrm{SCN})_{2} \mathrm{Br}_{2}$ receives charge from $\mathrm{NH}_{3}$ or $\mathrm{H}_{2} \mathrm{O}$, the band gap increases; when oxidative $\mathrm{O}_{2}$ molecules were absorbed, $\mathrm{Cs}_{2} \mathrm{~Pb}(\mathrm{SCN})_{2} \mathrm{Br}_{2}$ losses charge, the band gap decreases. It is well known that organometallic halide perovskites are ambipolar charge transporters due to the comparable effective masses of the electrons and holes. ${ }^{44,45}$ The adsorption of both the electron-donating $\left(\mathrm{NH}_{3}\right.$ and $\left.\mathrm{H}_{2} \mathrm{O}\right)$ and the electron-withdrawing $\left(\mathrm{O}_{2}\right)$ molecules can increase the electron- and hole-doping level of $\mathrm{Cs}_{2} \mathrm{~Pb}(\mathrm{SCN})_{2} \mathrm{Br}_{2}$, causing the materials to behave as $\mathrm{n}$ - or $\mathrm{p}$-type semiconductors.

\section{CONCLUSIONS}

In the current work, the influences of the adsorption of typical neutral $\mathrm{H}_{2} \mathrm{O}$, reductive $\mathrm{NH}_{3}$, and oxidative $\mathrm{O}_{2}$ on the surface of $\mathrm{Cs}_{2} \mathrm{~Pb}(\mathrm{SCN})_{2} \mathrm{Br}_{2}$ on the perovskite geometric structures are investigated. The adsorption energy and charge-transfer processes between the gas molecules and semiconductor materials are calculated as well. The main conclusions are as follows:

(1) The $\mathrm{Br}^{-}$doping, the $\mathrm{Pb}-\mathrm{NSC}$ connection formation, and the replacement of the polar and stick-like $\mathrm{CH}_{3} \mathrm{NH}_{3}^{+}$groups with the nonpolar and spherical CS cations together can effectively improve the structural stability of the perovskite materials. The quick adsorption of the gas molecules on the $\mathrm{Cs}_{2} \mathrm{~Pb}(\mathrm{SCN})_{2} \mathrm{Br}_{2}$ surface and the fast charge transfer between them indicate ideal molecular recognition and, therefore, potentially high sensitivity to the three types of gas. When put in a humid or reductive gas environment, sensors based on $\mathrm{Cs}_{2} \mathrm{~Pb}(\mathrm{SCN})_{2} \mathrm{Br}_{2}$ are expected to present enhanced stability; however, under the attack of strong oxidizing gas molecules, the $\mathrm{Pb}-\mathrm{Br}$ bonds are still not strong enough, which is a problem that warrants attention in the design of perovskite materials sensitive to strong oxidizing gases.

(2) Although the simulation time of $200 \mathrm{ps}$ is still too short compared with the actual adsorption-desorption process, $\mathrm{H}_{2} \mathrm{O}$ and $\mathrm{NH}_{3}$ can be stably adsorbed on the surface of $\mathrm{Cs}_{2} \mathrm{~Pb}(\mathrm{SCN})_{2} \mathrm{Br}_{2}$ in the dynamics simulations, and no desorption is observed. The electrons flow from the gases to the semiconductor materials. $\mathrm{O}_{2}$ is (a)

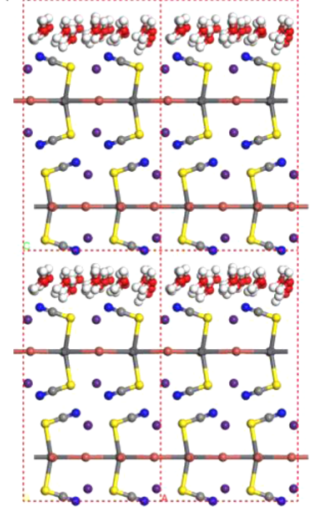

(b)

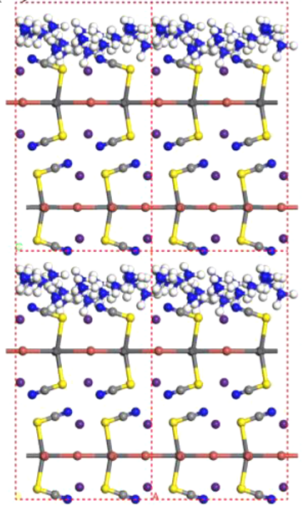

(c)

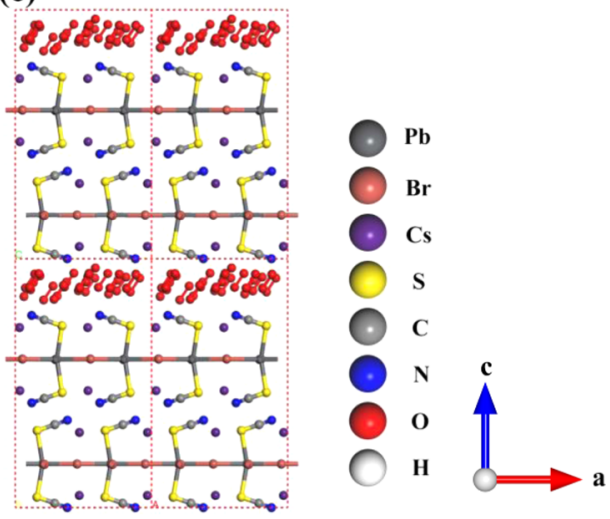

Figure 15. Initial structures of the three adsorption systems: (a) $\mathrm{Cs}_{2} \mathrm{~Pb}(\mathrm{SCN})_{2} \mathrm{Br}_{2}-\mathrm{H}_{2} \mathrm{O}$, (b) $\mathrm{Cs}_{2} \mathrm{~Pb}(\mathrm{SCN})_{2} \mathrm{Br}_{2}-\mathrm{NH}_{3}$, and $(\mathrm{c}) \mathrm{Cs}_{2} \mathrm{~Pb}(\mathrm{SCN})_{2} \mathrm{Br}_{2}-$ $\mathrm{O}_{2}$. 
frequently adsorbed or desorbed, and the charge flows from the semiconductor materials to $\mathrm{O}_{2}$. Based on these two different adsorption properties, the desorption properties of $\mathrm{O}_{2}$ on the $\mathrm{Cs}_{2} \mathrm{~Pb}(\mathrm{SCN})_{2} \mathrm{Br}_{2}$ surface are more favorable to improving the recovery time of gas sensors.

(3) The simulations suggest when put in a humid or reductive gas environment, sensors based on $\mathrm{Cs}_{2} \mathrm{~Pb}$ $(\mathrm{SCN})_{2} \mathrm{Br}_{2}$ are expected to present enhanced stability; however, under the attack of strong oxidizing gas molecules, the sensors can show high sensitivity but less stability than those in the neutral or reductive gases. This is because the $\mathrm{Pb}-\mathrm{Br}$ bonds are still not strong enough, which is a problem that warrants attention in the future design of perovskite materials sensitive to strong oxidizing gases.

\section{THEORETICAL METHODS}

The modeling structure of $\mathrm{Cs}_{2} \mathrm{~Pb}(\mathrm{SCN})_{2} \mathrm{Br}_{2}$ was first optimized by Vienna ab initio simulation package (VASP), ${ }^{46}$ which is built on the parent perovskite material $(\mathrm{MA})_{2} \mathrm{~Pb}$ $(\mathrm{SCN})_{2} \mathrm{I}_{2}{ }^{47}$ crystal structure. Slabs of $2 * 2$ from the bulk structure of $\mathrm{Cs}_{2} \mathrm{~Pb}(\mathrm{SCN})_{2} \mathrm{Br}_{2}$ were cut for $\mathrm{Cs}_{2} \mathrm{~Pb}(\mathrm{SCN})_{2} \mathrm{Br}_{2}-$ $\mathrm{H}_{2} \mathrm{O}, \mathrm{Cs}_{2} \mathrm{~Pb}(\mathrm{SCN})_{2} \mathrm{Br}_{2}-\mathrm{NH}_{3}$, and $\mathrm{Cs}_{2} \mathrm{~Pb}(\mathrm{SCN})_{2} \mathrm{Br}_{2}-\mathrm{O}_{2}$ systems. The $\mathrm{Cs}^{+}$-terminated $(001)^{48}$ perovskite surface was employed as the gas-exposed surface and a $5 \AA$ vacuum space was set along the c-direction, which was filled with $25 \mathrm{H}_{2} \mathrm{O}, 20$ $\mathrm{NH}_{3}$, and $20 \mathrm{O}_{2}$ molecules, respectively (Figure 15). The cell lattice parameters $a=12.05, b=12.55$, and $c=21.98 \AA$ for the complexes were used. In total, 163, 168, and 128 atoms are included in the $\mathrm{Cs}_{2} \mathrm{~Pb}(\mathrm{SCN})_{2} \mathrm{Br}_{2}-\mathrm{H}_{2} \mathrm{O}, \mathrm{Cs}_{2} \mathrm{~Pb}(\mathrm{SCN})_{2} \mathrm{Br}_{2}-$ $\mathrm{NH}_{3}$, and $\mathrm{Cs}_{2} \mathrm{~Pb}(\mathrm{SCN}){ }_{2} \mathrm{Br}_{2}-\mathrm{O}_{2}$ systems, respectively.

All of the $\mathrm{ab}$ initio dynamics simulations were carried out using the Car-Parrinello molecular dynamics (CPMD) ${ }^{49}$ module in the Quantum-Espresso package. ${ }^{50}$ Ultrasoft scalar relativistic pseudopotentials ${ }^{51}$ and the generalized gradient approximation with the Perdew-Burke-Ezernhof (PBE) function $^{52}$ were applied describing the exchange interaction between atoms. Plane-wave basis set cutoffs for the augmented density and the smooth part of the wave functions are $200 \mathrm{RY}$ and $25 \mathrm{RY}$, respectively. A fictitious electronic mass corresponds to $400 \mathrm{au}$. All of the dynamics calculations were conducted at a Nose-Hoover ${ }^{53}$ constant temperature of 300 $\mathrm{K}$. An integration time of 5 au was employed and the total simulation time was 200 ps for each system.

To describe quantitatively the influences of gas on the perovskite skeletons, the adsorption energy and charge transfer of the semiconductor-gas systems were computed every 5 ps. The structure optimization and comparisons of the stability of the $\mathrm{Pb}-\mathrm{SCN}$ and $\mathrm{Pb}-\mathrm{NCS}$ bonding were performed by the projected augmented wave $(\mathrm{PAW})^{54}$ plane-wave basis in VASP. The PBE calculations including the spin-orbit coupling $(\mathrm{SOC})^{55,56}$ were employed for all of the periodic complexes. The cutoff of the kinetic energy was set as $500 \mathrm{eV}$, and the electronic minimization was carried out with a tolerance of $10^{-4} \mathrm{eV}$. A Monkhorst-Pack k-point grid of $3 \times 3 \times 1$ was applied for the convergence of the energies and forces of the three adsorption systems. To reflect accurately the geometry variations and the electronic states of the adsorbed gas molecules on the perovskite materials, all of the coordinates of the atoms in the snapshots were left unoptimized. The adsorption energy was computed via equation

$$
E_{\text {ad }}=E_{(\text {perovskite+gas })}-E_{\text {perovskite }}-E_{\text {gas }}
$$

where $E_{\mathrm{ad}}, E_{(\text {perovskite+gas) }}, E_{\text {perovskite, }}$ and $E_{\text {gas }}$ are the adsorption energy of the complex, the total structural energy of perovskite and gas, the total structural energy of perovskite, and the structural energy of gas, respectively. The nonlocal van der Waals (VDW) contributions were considered with Grimmer's DFT-D3 correction $^{57}$ to probe the interactions between $\mathrm{Cs}_{2} \mathrm{~Pb}(\mathrm{SCN})_{2} \mathrm{Br}_{2}$ and the gas molecules.

The Bader charge population analysis ${ }^{58,59}$ was adopted to calculate the charge transfer between the gas molecules and the semiconductor material. The net charge transfer $\Delta Q$ is defined as follows

$$
\Delta Q_{X}=Q_{X}^{t=200}-Q_{X}^{t=0}
$$

where $X$ represents $\mathrm{Pb}^{2+}, \mathrm{Br}^{-}, \mathrm{SCN}^{-}, \mathrm{Cs}^{+}$, or gas, respectively.

\section{ASSOCIATED CONTENT}

\section{Supporting Information}

The Supporting Information is available free of charge at https://pubs.acs.org/doi/10.1021/acsomega.1c03952.

The RMSD curves of $\mathrm{CH}_{3} \mathrm{NH}_{3} \mathrm{PbI}_{3}-\mathrm{H}_{2} \mathrm{O}$ and $\left(\mathrm{CH}_{3} \mathrm{NH}_{3}\right)_{2} \mathrm{~Pb}(\mathrm{SCN})_{2} \mathrm{I}_{2}-\mathrm{H}_{2} \mathrm{O}$; the final structure of $\mathrm{CH}_{3} \mathrm{NH}_{3} \mathrm{PbI}_{3}-\mathrm{O}_{2}$ and $\left(\mathrm{CH}_{3} \mathrm{NH}_{3}\right)_{2} \mathrm{~Pb}(\mathrm{SCN})_{2} \mathrm{I}_{2}-\mathrm{O}_{2}$ adsorption complexes; the snapshots with the stable connections between $\mathrm{H}_{2} \mathrm{O}(\mathrm{a})-(\mathrm{c}), \mathrm{NH}_{3}(\mathrm{~d})-(\mathrm{f})$, and $\mathrm{O}_{2}(\mathrm{~g})-(\mathrm{i})$ and the surface of $\mathrm{Cs}_{2} \mathrm{~Pb}(\mathrm{SCN})_{2} \mathrm{Br}_{2}$, respectively; the adsorption energies of $\mathrm{Cs}_{2} \mathrm{~Pb}$ $(\mathrm{SCN})_{2} \mathrm{Br}_{2}-\mathrm{H}_{2} \mathrm{O}, \mathrm{Cs}_{2} \mathrm{~Pb}(\mathrm{SCN})_{2} \mathrm{Br}_{2}-\mathrm{NH}_{3}$, and $\mathrm{Cs}_{2} \mathrm{~Pb}$ $(\mathrm{SCN})_{2} \mathrm{Br}_{2}-\mathrm{O}_{2}$ adsorption complexes (PDF)

\section{AUTHOR INFORMATION}

\section{Corresponding Author}

Qiang Lu - National Engineering Laboratory for Biomass Power Generation Equipment, North China Electric Power University, Beijing 102206, P. R. China; School of New Energy and State Key Laboratory of Alternate Electrical Power System with Renewable Energy Sources, North China Electric Power University, Beijing 102206, P. R. China; (1) orcid.org/0000-0002-4340-1803; Phone: +86 10 61772030; Email: qlu@ncepu.edu.cn, qianglu@ mail.ustc.edu.cn; Fax: +86 $1061772032(801)$

\section{Authors}

Bing Zhang - National Engineering Laboratory for Biomass Power Generation Equipment, North China Electric Power University, Beijing 102206, P. R. China; School of New Energy and State Key Laboratory of Alternate Electrical Power System with Renewable Energy Sources, North China Electric Power University, Beijing 102206, P. R. China; (1) orcid.org/0000-0002-5758-0718

Xiaogang Wang - School of New Energy, North China Electric Power University, Beijing 102206, P. R. China

Yang Yang - School of New Energy, North China Electric Power University, Beijing 102206, P. R. China

Bin Hu - National Engineering Laboratory for Biomass Power Generation Equipment, North China Electric Power University, Beijing 102206, P. R. China; School of New Energy and State Key Laboratory of Alternate Electrical Power System with Renewable Energy Sources, North China Electric Power University, Beijing 102206, P. R. China; (1) orcid.org/0000-0003-2801-9873 
Lei Tong - School of New Energy, North China Electric Power University, Beijing 102206, P. R. China

Ying Liu - School of New Energy, North China Electric Power University, Beijing 102206, P. R. China

Li Zhao - National Engineering Laboratory for Biomass Power Generation Equipment, North China Electric Power University, Beijing 102206, P. R. China; School of New Energy, North China Electric Power University, Beijing 102206, P. R. China

Complete contact information is available at:

https://pubs.acs.org/10.1021/acsomega.1c03952

\section{Author Contributions}

B.Z. contributed to the conception of the study, wrote the paper together with B.H., X.W., Y.Y., and L.T., and performed the simulations and data processing. Y.Y. and Y.L. performed the data analyses and figure preparation. L.Z. and Q.L. contributed to the constructive discussions and data analyses.

\section{Notes}

The authors declare no competing financial interest.

\section{ACKNOWLEDGMENTS}

The authors acknowledge support from the National Natural Science Foundation of China (51922040, 51821004, and 51876060), the Fundamental Research Funds for the Central Universities (2020DF01 and 2020MS161), and the China Postdoctoral Science Foundation (2020M680482).

\section{REFERENCES}

(1) Kojima, A.; Teshima, K.; Shirai, Y.; Miyasaka, T. Organometal halide perovskites as visible-light sensitizers for photovoltaic cells. J. Am. Chem. Soc. 2009, 131, 6050-6051.

(2) Wehrenfennig, C.; Eperon, G. E.; Johnston, M. B.; Snaith, H. J.; Herz, L. M. High charge carrier mobilities and lifetimes in organolead trihalide perovskites. Adv. Mater. 2014, 26, 1584-1589.

(3) Roldán-Carmona, C.; Malinkiewicz, O.; Soriano, A.; Espallargas, G. M.; Garcia, A.; Reinecke, P.; Kroyer, T.; Dar, M. I.; Nazeeruddin, M. K.; Bolink, H. J. Flexible high efficiency perovskite solar cells. Energy Environ. Sci. 2014, 7, 994-997.

(4) Zhou, H.; Chen, Q.; Li, G.; Luo, S.; Song, T. B.; Duan, H. S.; Hong, Z.; You, J.; Liu, Y.; Yang, Y. Interface engineering of highly efficient perovskite solar cells. Science 2014, 345, 542-546.

(5) Safdari, M.; Fischer, A.; Xu, B.; Kloo, L.; Gardner, J. M. Structure and function relationships in alkylammonium lead (ii) iodide solar cells. J. Mater. Chem. A 2015, 3, 9201-9207.

(6) National Renewable Energy Laboratory, Best Research-cell Efficiency Chart, 2021, https://www.nrel.gov/pv/cell-efficiency.html (accessed Seven 2021)

(7) Conings, B.; Drijkoningen, J.; Gauquelin, N.; Babayigit, A.; D'Haen, J.; D'Olieslaeger, L.; Ethirajan, A.; Verbeeck, J.; Manca, J.; Mosconi, E.; Angelis, F. D.; Boyen, H. G. Intrinsic thermal instability of methylammonium lead trihalide perovskite. Adv. Energy Mater. 2015, 5, No. 1500477.

(8) Xing, J.; Liu, X. F.; Zhang, Q.; Ha, S. T.; Yuan, Y. W.; Shen, C.; Sum, T. C.; Xiong, Q. Vapor phase synthesis of organometal halide perovskite nanowires for tunable room-temperature nanolasers. Nano Lett. 2015, 15, 4571-4577.

(9) Dai, J.; Zheng, H.; Zhu, C.; Lu, J.; Xu, C. Comparative investigation on temperature-dependent photoluminescence of $\mathrm{CH}_{3} \mathrm{NH}_{3} \mathrm{PbBr}_{3}$ and $\mathrm{CH}\left(\mathrm{NH}_{2}\right)_{2} \mathrm{PbBr}_{3}$ microstructures. J. Mater. Chem. C 2016, 4, 4408-4413.

(10) Park, B. W.; Seok, S. I. Intrinsic Instability of InorganicOrganic Hybrid Halide Perovskite Materials. Adv. Mater. 2019, 31, No. 1805337.
(11) Zhao, Y.; Zhu, K. Optical bleaching of perovskite $\left(\mathrm{CH}_{3} \mathrm{NH}_{3}\right)$ $\mathrm{PbI}_{3}$ through room-temperature phase transformation induced by ammonia. Chem. Commun. 2014, 50, 1605-1607.

(12) Bao, C.; Yang, J.; Zhu, W.; Zhou, X.; Gao, H.; Li, F.; Fu, G.; Yu, T.; Zou, Z. A resistance change effect in perovskite $\mathrm{CH}_{3} \mathrm{NH}_{3} \mathrm{PbI}_{3}$ films induced by ammonia. Chem. Commun. 2015, 51, 15426-15429.

(13) Stoeckel, M. A.; Gobbi, M.; Bonacchi, S.; Liscio, F.; Ferlauto, L.; Orgiu, E.; Samori, P. Reversible, fast, and wide-range oxygen sensor based on nanostructured organometal halide perovskite. Adv. Mater. 2017, 29, No. 1702469.

(14) Kakavelakis, G.; Gagaoudakis, E.; Petridis, K.; Petromichelaki, V.; Binas, V.; Kiriakidis, G.; Kymakis, E. Solution processed $\mathrm{CH}_{3} \mathrm{NH}_{3} \mathrm{PbI}_{3-\mathrm{x}} \mathrm{Cl}_{\mathrm{x}}$ perovskite based self-powered ozone sensing element operated at room temperature. ACS Sens. 2018, 3, 135-142.

(15) Gupta, N.; Nanda, O.; Grover, R.; Saxena, K. A new inorganicorganic hybrid halide perovskite thin film based ammonia sensor. Org. Electron. 2018, 58, 202-206.

(16) Jiao, W.; He, J.; Zhang, L. Synthesis and high ammonia gas sensitivity of $\left(\mathrm{CH}_{3} \mathrm{NH}_{3}\right) \quad \mathrm{PbBr}_{3-x} \mathrm{I}_{x}$ perovskite thin film at room temperature. Sens. Actuators, B 2020, 309, No. 127786.

(17) Fu, X.; Jiao, S.; Dong, N.; Lian, G.; Zhao, T.; Lv, S.; Wang, Q.; Cui, D. A CH $\mathrm{CH}_{3} \mathrm{PbI}_{3}$ film for a room-temperature $\mathrm{NO}_{2}$ gas sensor with quick response and high selectivity. RSC Adv. 2018, 8, 390-395.

(18) Ren, K.; Huang, L.; Yue, S.; Lu, S.; Liu, K.; Azam, M.; Wang, Z.; Wei, Z.; Qu, S.; Wang, Z. Turning a disadvantage into an advantage: synthesizing high-quality organometallic halide perovskite nanosheet arrays for humidity sensors. J. Mater. Chem. C 2017, 5, 2504-2508.

(19) Ganose, A. M.; Savory, C. N.; Scanlon, D. O. $\left(\mathrm{CH}_{3} \mathrm{NH}_{3}\right)_{2} \mathrm{~Pb}-$ $(\mathrm{SCN})_{2} \mathrm{I}_{2}$ : A more stable structural motif for hybrid halide photovoltaics? J. Phys. Chem. Lett. 2015, 6, 4594-4598.

(20) Zhang, B.; Zhou, S. J.; Tong, L.; Liao, Y. J.; Yi, J. X.; Qi, Y.; Yao, J. X. Large scale quantum dynamics investigations on the sensing mechanism of $\mathrm{H}_{2} \mathrm{O}$, acetone, $\mathrm{NO}_{2}$ and $\mathrm{O}_{3}$ adsorption on the $(\mathrm{MA})_{2} \mathrm{~Pb}(\mathrm{SCN})_{2} \mathrm{I}_{2}$ surface. Phys. Chem. Chem. Phys. 2019, 21, 21223-21235.

(21) Tong, L.; Zhang, B.; Wang, X. G.; Liao, Y. J.; Yang, J. Q. Quantum dynamics simulations on the adsorption mechanism of reducing and oxidizing gases on the $\mathrm{CH}_{3} \mathrm{NH}_{3} \mathrm{PbI}_{3}$ surface. $A d v$. Theory Simul. 2020, 3, No. 2000024.

(22) Li, C. H.; Tsai, C. C.; Liao, M. Y.; Su, Y. A.; Lin, S. T.; Chueh, C. C. Stable, color-tunable 2D SCN-based perovskites: revealing the critical influence of an asymmetric pseudo-halide on constituent ions. Nanoscale 2019, 11, 2608-2616.

(23) Chen, H.; Zhang, M.; Bo, R.; Barugkin, C.; Zheng, J.; Ma, Q.; Huang, S.; Ho-Baillie, A. W. Y.; Catchpole, K. R.; Tricoli, A. Superior self-powered room-temperature chemical sensing with light-activated inorganic halides perovskites. Small 2018, 14, No. 1702571.

(24) Wu, S.; Fan, Z.; Wang, W.; Fan, H.; Mei, Z.; Sun, D.; Cheng, X.; Zhao, X.; Tian, Y. Microfabricable ratiometric gaseous oxygen sensors based on inorganic perovskite nanocrystals and PtTFPP. Sens. Actuators, B 2018, 271, 104-109.

(25) Yamazoe, N.; Sakai, G.; Shimanoe, K. Oxide semiconductor gas sensors. Catal. Surv. Asia 2003, 7, 63-75.

(26) Kaewmaraya, T.; Ngamwongwan, L.; Moontragoon, P.; Jarernboon, W.; Singh, D.; Ahuja, R.; Karton, A.; Hussain, T. Novel green phosphorene as a superior chemical gas sensing material. $J$. Hazard. Mater. 2021, 401, No. 123340.

(27) Hussain, T.; Panigrahi, P.; Ahuja, R. Sensing propensity of a defected graphane sheet towards $\mathrm{CO}, \mathrm{H}_{2} \mathrm{O}$ and $\mathrm{NO}_{2}$. Nanotechnology 2014, 25, No. 325501.

(28) Pannopard, P.; Khongpracha, P.; Probst, M.; Limtrakul, J. Gas sensing properties of platinum derivatives of single-walled carbon nanotubes: A DFT analysis. J. Mol. Graphics Modell. 2009, 28, 62.

(29) Lee, G. Y.; Yang, M. Y.; Kim, D. H.; Lim, J.; Byun, J.; Choi, D. S.; Lee, H. J.; Nam, Y. S.; Kim, I.; Kim, S. O. Nitrogen-DopantInduced Organic-Inorganic Hybrid Perovskite Crystal Growth on Carbon Nanotubes. Adv. Funct. Mater. 2019, 29, No. 1902489. 
(30) Kim, S. J.; Park, Y. J.; Ra, E. J.; Kim, K. K.; An, K. H.; Lee, Y. $\mathrm{H}$.; et al. Defect-induced loading of $\mathrm{Pt}$ nanoparticles on carbon nanotubes. Appl. Phys. Lett. 2007, 90, No. 023114.

(31) Goldoni, A.; Larciprete, R.; Petaccia, L.; Lizzit, S. Single-wall carbon nanotube interaction with gases: sample contaminants and environmental monitoring. J. Am. Chem. Soc. 2003, 125, 1132911333.

(32) Collins, P. G.; Bradley, K.; Ishigami, M.; Zettl, A. Extreme oxygen sensitivity of electronic properties of carbon nanotubes. Science 2000, 287, 1801-1804.

(33) Peng, S.; Cho, K. Ab initio study of doped carbon nanotube sensors. Nano Lett. 2003, 3, 513-517.

(34) Kim, M. C.; Ahn, N.; Lim, E.; Jin, Y. U.; Pikhitsa, P. V.; Heo, J.; Kim, S. K.; Jung, H. S.; Choi, M. Degradation of $\mathrm{CH}_{3} \mathrm{NH}_{3} \mathrm{PbI}_{3}$ perovskite materials by localized charges and its polarity dependency. J. Mater. Chem. A 2019, 7, 12075-12085.

(35) Mosconi, E.; Azpiroz, J. M.; Angelis, F. D. Ab Initio Molecular Dynamics Simulations of Methylammonium Lead Iodide Perovskite Degradation by Water. Chem. Mater. 2015, 27, 4885-4892.

(36) Zhang, L.; Yu, F.; Li, Q.; Su, J.; Li, J.; Li, M. Understanding interactions between halide perovskite surfaces and atmospheric/ VOC gas molecules: an ab initio investigation. J. Phys. D: Appl. Phys. 2018, 51, No. 315302.

(37) Zhang, L.; Ju, M. G.; Liang, W. The effect of moisture on the structures and properties of lead halide perovskites: A first-principles theoretical investigation. Phys. Chem. Chem. Phys. 2016, 18, 2317423183.

(38) Long, R.; Fang, W.; Prezhdo, O. V. Moderate humidity delays electron-hole recombination in hybrid organic-inorganic perovskites: Time-domain $\mathrm{ab}$ initio simulations rationalize experiments. J. Phys. Chem. Lett. 2016, 7, 3215-3222.

(39) Zhang, L.; Sit, P. H. L. Ab initio static and dynamic study of $\mathrm{CH}_{3} \mathrm{NH}_{3} \mathrm{PbI}_{3}$ degradation in the presence of water, hydroxyl radicals, and hydroxide ions. RSC Adv. 2016, 6, 76938-76947.

(40) Zhang, B.; Liao, Y. J.; Tong, L.; Yang, Y. Q.; Wang, X. G. Ion migration in Br-doped $\mathrm{MAPbI}_{3}$ and its inhibition mechanisms investigated via quantum dynamics simulations. Phys. Chem. Chem. Phys. 2020, 22, 7778-7786.

(41) Wells, A. F. Structural Inorganic Chemistry; Oxford University Press: Oxford, 2012.

(42) Geiger, D. K.; Parsons, D. E.; Zick, P. L. Crystal structures of three lead (II) acetate-bridged diaminobenzene coordination polymers. Acta Crystallogr., Sect. E: Struct. Rep. Online 2014, 70, 566-572.

(43) Pauling, L.; Kamb, B. Linus Pauling: Selected Scientific Papers; World Scientific: Singapore, 2001.

(44) Ball, J. M.; Lee, M. M.; Hey, A.; Snaith, H. J. Low-temperature processed meso-superstructured to thin-film perovskite solar cells. Energy Environ. Sci. 2013, 6, 1739-1743.

(45) Giorgi, G.; Fujisawa, J. I.; Segawa, H.; Yamashita, H. Cation role in structural and electronic properties of $3 \mathrm{D}$ organic-inorganic halide perovskites: A DFT analysis. J. Phys. Chem. C 2014, 118, 12176-12183.

(46) Kresse, G.; Furthmüller, J. Efficiency of ab-initio total energy calculations for metals and semiconductors using a plane-wave basis set. Comput. Mater. Sci. 1996, 6, 15-50.

(47) Daub, M.; Hillebrecht, H. Synthesis, Single-Crystal Structure and Characterization of $\left(\mathrm{CH}_{3} \mathrm{NH}_{3}\right)_{2} \mathrm{~Pb}(\mathrm{SCN})_{2} \mathrm{I}_{2}$. Angew. Chem., Int. Ed. 2015, 54, 11016-11017.

(48) The original crystal structure of $\left(\mathrm{CH}_{3} \mathrm{NH}_{3}\right)_{2} \mathrm{~Pb}(\mathrm{SCN})_{2} \mathrm{I}_{2}$ has been rotated 90 degrees counterclockwise around the $\mathrm{B}$ axis to keep exposed adsorption surface consistent with that of $\mathrm{MAPbI}_{3}$ in one of our previous work. The built structure of $\mathrm{Cs}_{2} \mathrm{~Pb}(\mathrm{SCN})_{2} \mathrm{Br}_{2}$ in the current work is based on the rotated $\left(\mathrm{CH}_{3} \mathrm{NH}_{3}\right)_{2} \mathrm{~Pb}(\mathrm{SCN})_{2} \mathrm{I}_{2}$ frame, the surface for adsorption is, therefore, $\left(\begin{array}{lll}0 & 0 & 1\end{array}\right)$.

(49) Car, R.; Parrinello, M. Unified approach for molecular dynamics and density-functional theory. Phys. Rev. Lett. 1985, 55, $2471-2474$.
(50) Giannozzi, P.; Baroni, S.; Bonini, N.; Calandra, M.; Car, R.; Cavazzoni, C.; Ceresoli, D.; Chiarotti, G. L.; Cococcioni, M.; Dabo, I.; et al. QUANTUM ESPRESSO: a modular and open-source software project for quantum simulations of materials. J. Phys.: Condens. Matter 2009, 21, No. 395502.

(51) Laasonen, K.; Pasquarello, A.; Car, R.; Lee, C.; Vanderbilt, D. Car-Parrinello molecular dynamics with Vanderbilt ultrasoft pseudopotentials. Phys. Rev. B 1993, 47, 10142.

(52) Perdew, J. P.; Burke, K.; Ernzerhof, M. D. Generalized Gradient Approximation Made Simple. Phys. Rev. Lett. 1996, 77, 3865.

(53) Shuichi, N. Constant temperature molecular dynamics methods. Prog. Theor. Phys. Suppl. 1991, 103, 1-46.

(54) Blöchl, P. E. Projected augmented-wave method. Phys. Rev. B 1994, 50, 17953.

(55) Neese, F. Efficient and accurate approximations to the molecular spin-orbit coupling operator and their use in molecular gtensor calculations. J. Chem. Phys. 2005, 122, No. 034107.

(56) Even, J.; Pedesseau, L.; Jancu, J. M.; Katan, C. Importance of Spin-Orbit Coupling in Hybrid Organic/Inorganic Perovskites for Photovoltaic Applications. J. Phys. Chem. Lett. 2013, 4, 2999-3005.

(57) Grimme, S.; Antony, J.; Ehrlich, S.; Krieg, H. A consistent and accurate $\mathrm{ab}$ initio parametrization of density functional dispersion correction (DFT-D) for the 94 elements H-Pu. J. Chem. Phys. 2010, 132, No. 154104.

(58) Sanville, E.; Kenny, S. D.; Smith, R.; Henkelman, G. Improved grid-based algorithm for Bader charge allocation. J. Comput. Chem. 2007, 28, 899-908.

(59) Tang, W.; Sanville, E.; Henkelman, G. A grid-based Bader analysis algorithm without lattice bias. J. Phys.: Condens. Matter 2009, 21, No. 084204. 